\title{
Making sense of medieval mouths: Investigating sex differences of dental pathological lesions in a late medieval Italian community
}

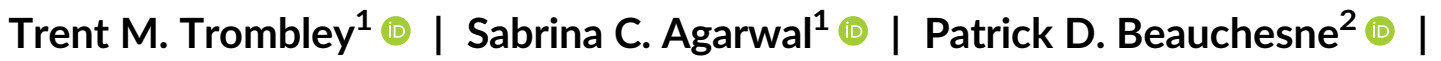 \\ Caroline Goodson $^{3}$ | Francesca Candilio ${ }^{4,5}$ | Alfredo Coppa ${ }^{6}$ | Mauro Rubini ${ }^{7,8}$
}

${ }^{1}$ Department of Anthropology, University of California, Berkeley, Berkeley, California

${ }^{2}$ Department of Behavioral Sciences, University of Michigan, Dearborn, Dearborn, Michigan

${ }^{3}$ Faculty of History, University of Cambridge, King's College, Cambridge, United Kingdom

${ }^{4}$ Anthropological Service, Soprintendenza Archeologia, Belle Arti e Paesaggio per la città metropolitana di Cagliari e le province di Oristano e Sud Sardegna, Cagliari, Italy

${ }^{5}$ Physical Anthropology Section, University of Pennsylvania Museum of Archaeology and Anthropology, Philadelphia, Pennsylvania

${ }^{6}$ Department of Environmental Biology, Sapienza University of Rome, Rome, Italy

${ }^{7}$ Department of Archaeology, Foggia University, Foggia, Italy

${ }^{8}$ Anthropological Service, S.A.B.A.P.-LAZ,

Rome, Italy

Correspondence

Trent M. Trombley, Department of Anthropology, University of California, Berkeley, 134 West 20th Street, Merced, Berkeley, CA 95340.

Email: ttrombley001@berkeley.edu

Funding information

University of California, Berkeley's

Archaeological Research Facility Stahl Faculty grant; University of Michigan, Dearborn's Rackham grant

\begin{abstract}
Objectives: Bioarchaeological investigations of sex-based differences in the prevalence of dental pathological lesions, particularly caries, have drawn considerable attention, and out of this work, two dominant models have emerged. Traditionally, the first model interprets sex-related patterns in caries as a product of gendered differences in diet. A more recent model interprets a generally higher propensity for caries prevalence in females in light of reproductive ecology. To test the hypothesis that females have higher risk of caries in accordance with reproductive ecology, we examined and analyzed caries prevalence and other potentially synergistic oral pathological lesions in a late medieval (A.D. 1300-1500) Italian archaeological sample.

Materials and methods: We examined sex- and age-related prevalence in caries and other oral pathological lesions in a late medieval Italian skeletal assemblage excavated from Villamagna consisting of 38 females and 37 males ( $n=1,534$ teeth). We examined age- and sex-related patterns in six dental traits: antemortem tooth loss, caries, calculus, periapical inflammation, tooth wear, and periodontitis.

Results: Significant age-related increases in antemortem tooth loss, caries, calculus, and tooth wear were observed in both males and females. However, there was a lack of expected sex differences in oral pathological lesions, with instead older males exhibiting significantly more antemortem tooth loss and corrected caries than females.

Discussion: Results are discussed in relation to the ethnohistoric context of medieval rural dietary practices as well as biomedical salivary literature, which suggest that dietary changes throughout the life course may have facilitated trade-offs that buffered females from higher rates of dental pathological lesions.
\end{abstract}

\section{KEYWORDS}

bioarchaeology, caries, dental anthropology, reproductive ecology, saliva

\section{1 | INTRODUCTION}

The analysis of oral pathological lesions has a long history in bioarchaeology, ranging from studies of dietary reconstruction (Powell, 1985; Temple, 2007; Turner, 1979), subsistence strategies (Cohen \& Armelagos, 1984; Cohen \& Cane-Kramer, 2007; Rose, Marks, \& Tiezen, 1991; Temple \& Larsen, 2007; Walker \& Hewlett, 1990), colonial encounters (Klaus \& Tam, 2010; Larsen \& Milner, 1994), reproductive ecology (Lukacs, 1996; Lukacs, 2008; Lukacs, 2017; Lukacs \& Largaespada, 2006), to frailty (DeWitte \& Bekvalac, 2010). Because of their highly mineralized structure, human teeth preserve well in archaeological contexts and offer a reliable source of biosocial information on past communities.

Sex-related difference in prevalence is frequently examined in bioarchaeological studies of oral health. Differences in oral pathological lesions between sexes are often interpreted within two models: dietarybehavioral hypotheses and reproductive ecology hypotheses (Fields, Herschaft, Martin, \& Watson, 2009; Klaus \& Tam, 2010; Larsen, 1983; Lukacs, 1996; Lukacs, 2008; Lukacs, 2017; Lukacs \& Largaespada, 2006; Lukacs \& Pal, 1993; Temple \& Larsen, 2007; Watson, Fields, \& 
Martin, 2010). The former model often interprets differences in oral health between males and females as a result of dietary differences between sexes. Specifically, a number of bioarchaeological studies have attributed differences in carious lesions between sexes as a product of dietary variability, with males having greater access to protein-rich resources such as meat and marine resources, whereas females probably relied on terrestrial plant materials and starchy cultigens (Kelley, Levesque, \& Weidle, 1991; Klaus \& Tam, 2010; Larsen, 1983; Larsen, Shavit, \& Griffin, 1991; Lukacs, 1996; Lukacs \& Pal, 1993; Novak, 2015; Tayles, Domett, \& Nelsen, 2000; Temple \& Larsen, 2007; Walker \& Hewlett, 1990). Thus, these sex-based differences in carious frequencies are believed to be due to differential consumption of cariogenic foods between males and females.

The latter, more recent, model posits that sex differences in caries frequency are more likely attributable to age- and fertility-related alterations in oral biology as a result of reproductive biology. This model emphasizes peri-reproductive increases in hormones such as estrogen and progesterone and their subsequent impact on gingival tissues and salivary production and quality, which act as buffers to cariogenic bacteria (Burakoff, 2003; Laine, 2002; Silk, Douglass, Douglass, \& Silk, 2008; Steinberg, 2000). Heightened estrogen levels during pregnancy are posited as a risk factor for caries and gingival damage in that they detrimentally affect saliochemical and saliometric profiles that are crucial in maintaining oral homeostasis. Bioarchaeological studies that have observed a significantly higher prevalence of caries in females have attributed differences to hormone-related changes in female fertility and salivary hypofunction, suggesting this ultimately places reproductive age females at risk for increased cariogenic activity or antemortem tooth loss compared to their male counterparts (Lukacs, 1996; Lukacs, 2008; Lukacs, 2017; Lukacs \& Largaespada, 2006; Watson et al., 2010). Sex differences are often interpreted within the context of biomedical and animal feeding studies, that demonstrate pregnancy-related changes to female oral microbial flora and ecology as a result of increased estrogen levels (Arantes, Santos, Frazao, \& Coimbra, 2009; Fields et al., 2009; Kolenbrander \& Palmer, 2004; Marsh, 2004).

However, sex differences in carious lesions are not a universal, as a number of studies have found that expected sex differences in caries frequencies are either small or nonexistent (Douglas, 2006; Larsen, 1983, 1998; Šlaus, Bedić, Bradić, Vodanović, \& Brkić, 2017; Temple \& Larsen, 2007). Analyzing caries frequencies by sex and age in a Late/Final Jomon skeletal assemblage, Temple (2011) found that although females exhibited higher caries prevalence compared to their male counterparts in each age category, the study failed to show significant increases in caries prevalence and mean number of carious teeth across female age groups. Temple (2011) also compared caries prevalence between the high- and low-density sites of Tokai and Sanyo, to further evaluate potential effects of birth rate and fertility on caries in light of the reproductive ecology hypothesis. Although results showed a significantly increased caries prevalence among high-density Tokai female molars in the older age category compared to low-density Sanyo female molars, Temple (2011: 114) ultimately cautions that population decline in Tokai, paired with lack of other significant female caries prevalence differences suggests that reproductive factors likely played a minor role in the manifestation of caries when compared to behavioral and dietary factors. Such variation in caries prevalence across time and space underscores the complex etiology of cariogenesis and the synergistic interplay with dietary variation, oral biochemistry, and hormones.

While not mutually exclusive, these models do preferentially emphasize different aspects of the biocultural spectrum. Differing explanations of the complex etiology of cariogenesis have helped to broaden the bioarchaeological understanding of the ultimate causes of dental pathological lesions. For instance, the role of saliva and its relation to caries in bioarchaeological studies was relatively underappreciated until recently (Lukacs, 2017; Lukacs \& Largaespada, 2006). Saliva has been clinically demonstrated to act as an inhibitor to carcinogenesis due to its ability to: (1) lubricate and cleanse the oral cavity, (2) buffer against acidogenic bacteria and oral $\mathrm{pH}$ through bicarbonates, and (3) remineralize enamel through calcium phosphates (Amerongen \& Veerman, 2002; de Almeida, Grégio, Machado, de Lima, \& Azevedo, 2008; Dowd, 1999; Lenander-Lumikari \& Loimaranta, 2000; Vitorino, Calheiros-Lobo, Duarte, Domingues, \& Amado, 2006). Yet despite the crucial importance of saliva in relation to caries, it is near impossible to reconstruct saliometric and saliochemical profiles in archaeological skeletal remains. Furthermore, emphasis on the role of salivary flows and chemistry over dietary or behavioral explanations can be problematic if there has been no systematic examination of sex-based dietary differences using other sources such as stable isotopic analyses or ethnohistoric data.

Although the protective role of saliva is relatively well known, the production of saliva is further complicated by non-hormonal factors. Three major salivary glands; the parotid, submandibular, and sublingual glands are responsible for producing nearly $90 \%$ of the saliva that enters the oral cavity (Navazesh \& Kumar, 2008), supplemented by minor salivary glands which are usually located throughout the oral cavity in the submucosa (Hand, Pathmanathan, \& Field, 1999). Saliva is often classified as either "whole saliva," which refers to the total saliva produced from gland secretions, or "glandular saliva" which refers to saliva originating from specific glands (Sreebny, 2000). Saliva is further differentiated by alimentary stimulation as resting/unstimulated and stimulated. Although resting saliva originates predominately from the submandibular and sublingual glands, stimulation alters the relative contribution of salivary glands to the parotid gland (Navazesh \& Kumar, 2008; Sreebny, 2000) and additionally results in a three- to five-fold increase in salivary production and flow (Pedersen, Schubert, Izutsu, Mersai, \& Truelove, 1985). Crucially, stimuli can arise from not only from exposure to acidity but also mechanically from repeated chewing and bite force (Navazesh \& Kumar, 2008: 37S). This is likely a product of mechanoreceptors within the periodontal membrane (Anderson \& Hector, 1987; Anderson, Hector, \& Linden, 1996; Hector \& Linden, 1987), such that when teeth occlude, the resulting compression activates periodontal mechanoreceptors which then trigger impulses through the trigeminal nerve to produce saliva (Pedersen et al., 1985; Scott, Bajaj, \& Linden, 1999). Hardness and size of chewed substrates as well as bite force are positively correlated with increased salivary production (Anderson \& Hector, 1987; Hector \& Linden, 1987; Rosenhek, MacPherson, \& Dawes, 1993). Although it is not known how dietary differences between individuals may influence downstream effects on saliochemical production, there does seem to be evidence that diets requiring repeated and exerted chewing efforts 
result in increased salivary flow and production originating from the parotid gland. The rheological properties of food (i.e., food texture) has been shown to correspond with temporalis and masseter muscle activities (Agrawal, Lucas, Bruce, \& Prinz, 1998; Bishop, Plesh, \& McCall, 1990; Gavião, Engelen, \& van der Bilt, 2004; Mioche, Bouriol, Martin, \& Noël, 1999) and salivary flow (Mackie \& Pangborn, 1990; Pereira, Gavião, \& van der Bilt, 2006). In controlled feeding studies with rats, liquid diets resulted in reduced salivary production and atrophy of the parotid gland, where coarser diets that required more mastication resulted in higher salivary production (Hall \& Schneyer, 1964; Johnson, 1984; Johnson \& Sreebny, 1973). The same patterns have been observed in humans, where firmer foods showed a $40 \%$ increase in saliva of the parotid gland and an overall increase in $\mathrm{pH}$ levels in the mouth (de Muñiz, Maresca, Tumilasci, \& Perec, 1983). Experimental studies with sugar-free gums have also demonstrated increased salivary flow and increases in salivary $\mathrm{pH}$ as a result of alimentary and mechanical stimulation (Bots, Brand, Veerman, van Amerongen, \& Nieuw Amerongen, 2004; Dawes \& Kubieniec, 2004; Dawes \& Macpherson, 1992; Polland, Higgins, \& Orchardson, 2003; Rosenhek et al., 1993). Masticatory factors such as bite force, chewing frequency, and muscle activity as well as gustatory and alimentary stimulation thus all seem to contribute to salivary production as well as salivary pH (Dodds, Hsieh, \& Johnson, 1991; Dodds \& Johnson, 1993; Ikebe et al., 2007; Jenkins \& Edgar, 1989; Yeh et al., 2000). As such, consideration of masticatory factors could therefore be potentially revealing in bioarchaeological analyses with comparisons of tooth wear and caries.

This research focuses on a number of indicators of oral health in the medieval Italian skeletal assemblage of Villamagna. Following the reproductive ecological model of cariogenesis, we test the hypothesis that females will show a greater prevalence of caries and other dental pathological lesions. We expect sex differences in dental pathological lesions to be especially marked in the older age category, based on the premise that females would be more likely to have had multiple pregnancies by this age, and therefore, pregnancy-related elevations in hormones should correspond to increases in carious lesions throughout the lifecourse. Although we evaluate caries prevalence and other dental pathological lesions in the context of these predominating models, we also seek to examine the possible interplay between salivary and dietary factors, given the aforementioned relationship between mastication, food texture, and saliva. In doing so, we aim to weigh the relative contributions of diet and possible salivary production as evidence by dental lesions within the biocultural and ethnohistoric context of agrarian medieval Italy.

\section{2 | MATERIALS}

Villamagna is located in the Sacco Valley of the Lazio region, approximately $65 \mathrm{~km}$ southeast of Rome (Figure 1). It was the site of a large Imperial estate, initially established in the second century and frequented by the young Marcus Aurelius before his becoming emperor (Fentress \& Maiuro, 2011). At the site, there was a monastery and peasant village from the late tenth century to the late thirteenth century, at which point the settlement was transformed into a castrum or fortified village lasting until the early fifteenth century (Fentress, Goodson, \& Maiuro, 2016 ). Archaeological excavation of the site was carried out from 2006 to 2010 , revealing a cemetery skeletal assemblage in proximity to the medieval monastery and its church, S. Pietro (Goodson, 2016). With varying demographics of males ( $n=107)$, females $(n=93)$, and subadults $(n=204)$, the cemetery has been interpreted as a representative sample of a rural population who had labor ties to the estate, not a monastic cemetery itself which would probably be characterized by exclusively male burials (Fentress et al., 2016).

This study examines the well-preserved individuals from the late medieval period cemetery (c. 1300-1500), in association with the castrum ( $n=382$ total individuals; 79 males, 65 females, 61 indeterminate sex, and 177 subadults) (Candilio \& Cox, 2016). All juveniles and adolescents were excluded from this study, due to issues in deciduous dental preservation. In addition, adult individuals who (1) could not be assigned an age category, (2) exhibited poorly preserved or damaged dentition, or (3) showed substantive fragmentation of alveolar structures were also excluded. Although this restricted our final sample size, our conservative threshold was implemented to retain individuals whose observable dentition and oral cavities were relatively complete and therefore permit the recording of multiple dental pathological lesions. The resulting subsample analyzed in this study consists of 75 adult individuals ( $n=38$ females, $n=37$ males) representing $n=1,534$ teeth (Table 1 ).

Dietary subsistence at Villamagna consisted largely of cereal cultigens and terrestrial herbivorous fauna. Documentary evidence from the central medieval period (c. 1000-1300) at Villamagna details records of produce and agrarian products tied to the monastic lands, such as wheat (Triticum sp.), barley (Hordeum vulgare), broad beans (Vicia faba), and chickpeas (Cicer arietinum) (Goodson, 2016); it is reasonable to assume that similar crops were grown in the late medieval phase. Zooarchaeological analyses were limited by the degree of preservation but revealed the presence of terrestrial faunal domesticates typical of medieval agrarian contexts, such as sheep/goat (Ovis aries/Capra hircus), pigs (Sus scrofa), cattle (Bos taurus) and horses (Equus sp.) in the central medieval phase (Holt, 2016). Faunal percentages could reflect changes to agricultural land practices whereby larger terrestrial livestock such as cattle could not be readily sustained due to possible limitations placed on grazing rights of the peasant community. Overall, temporal changes in fauna accompanied by an increasing reliance on smaller livestock and poultry and more varied age-at-death pattern in faunal assemblages suggestive of a "mixed-farming strategy" of the central medieval period, whereby fauna were raised and consumed within households and not for larger production purposes (Holt, 2016).

Previous isotopic analyses conducted by Nitsch (2016) at Villamagna also help to contextualize medieval dietary patterns at the site. Using stable carbon $\delta^{13} \mathrm{C}$ and nitrogen $\delta^{15} \mathrm{~N}$ isotopes from rib collagen of 98 late medieval adults ( $n=33$ females, $n=45$ males) and 85 subadults, Nitsch (2016) found that Villamagna had relatively lower $\delta^{13} \mathrm{C}$ and $\delta^{15} \mathrm{~N}$ values compared to other Italian sites such as the 15th-century Palazzo della Cancelleria in Rome and 8th- to 13th-century Trino Vercellese from northern Italy. This study suggested that dietary regimens within rural Lazio consisted of foodstuffs lower in $\delta^{13} \mathrm{C}$ and $\delta^{15} \mathrm{~N}$ compared to larger cities such as Rome (Nitsch, 2016). However, isotopic analyses also 


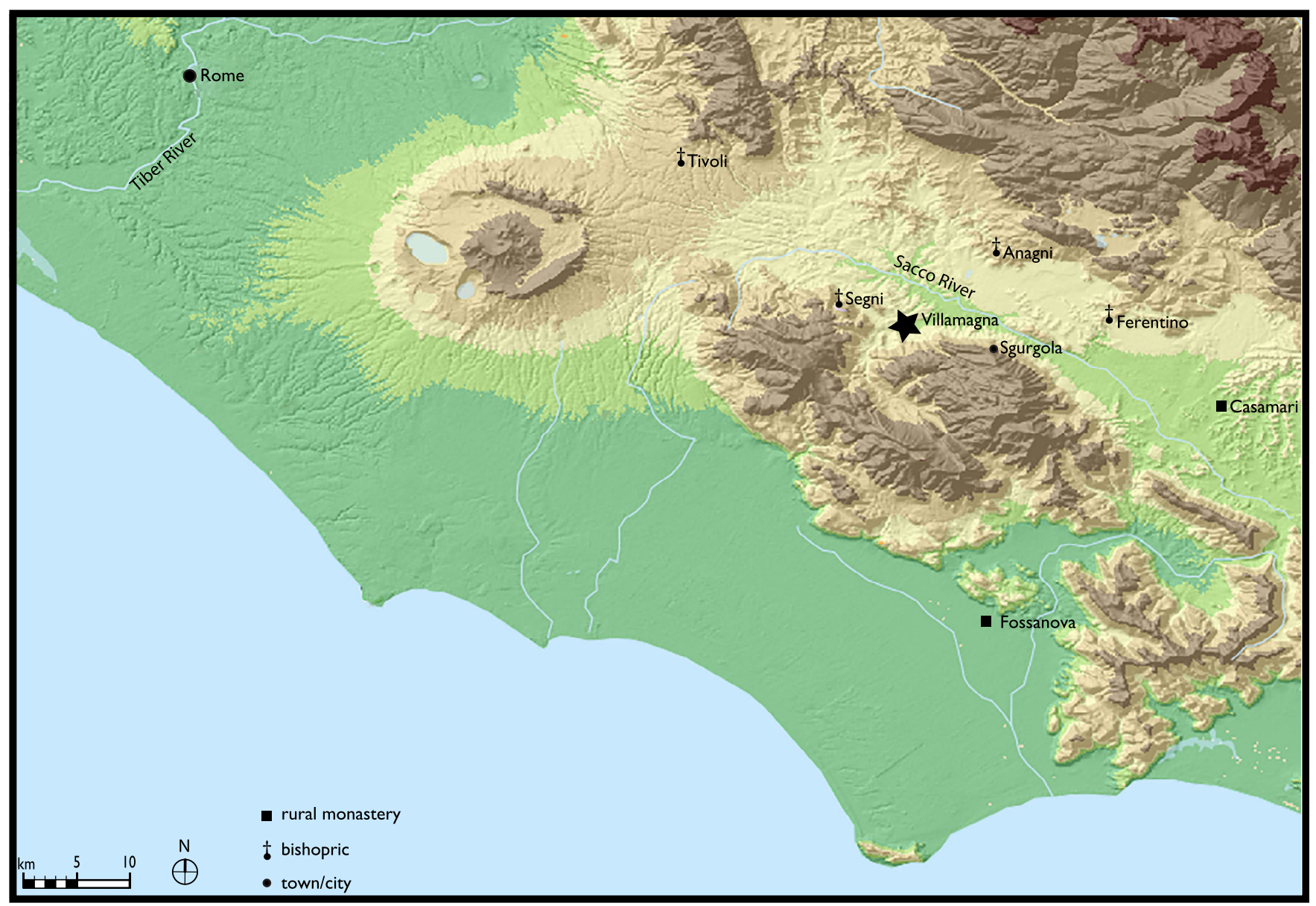

FIGURE 1 Location of Villamagna in Lazio [Map: Goodson based upon Ancient World Mapping Center, http://awmc.unc.edu/awmc/applications/ alacarte/]

revealed that individuals from Villamagna did have higher values of $\delta^{13} \mathrm{C}$ and $\delta^{15} \mathrm{~N}$ than local fauna such as goats, sheep, cattle, and pigs, suggesting consumption of these animals or of other proteinatious sources such as marine resources or manured crops. Overall, temporal changes in isotopic values were minor, suggesting that the bulk dietary components of the inland Lazio region remained relatively similar over an 800-year period (Nitsch, 2016).

Significant differences in $\delta^{13} \mathrm{C}$ and $\delta^{15} \mathrm{~N}$ isotope values were found between adults and sub-adults (Nitsch, 2016). Increased $\delta^{15} \mathrm{~N}$ values by a level of $3-4 \%$ of the female adult mean were noted in the first 2 years of life, likely indicating trophic enrichment coinciding with breastfeeding. These levels returned to the female adult mean $\delta^{15} \mathrm{~N}$ values by $2-2.5$ years of age, ultimately suggesting that weaning likely took place around 2 years of age (Nitsch, 2016). When comparing adult stable isotopic values by sex, results showed males to have slightly higher values for $\delta^{15} \mathrm{~N}$ and $\delta^{13} \mathrm{C}$, which was found to be statistically significant. Nitsch (2016) suggests that males may have had

TABLE 1 Sample distribution of the Villamagna skeletal population

\begin{tabular}{lccl} 
Age (years) & Females & Males & Total \\
\hline $18-29$ & 9 & 10 & 19 \\
$30-49$ & 20 & 24 & 44 \\
\hline $50+$ & 9 & 3 & 12 \\
Total & 38 & 37 & 75 \\
\hline
\end{tabular}

more access to foodstuffs higher in $\delta^{13} \mathrm{C}$ and $\delta^{15} \mathrm{~N}$, such as faunal protein and marine resources, whereas females may have had a heavier reliance on terrestrial cultigens at Villamagna. Nitsch (2016) suggests that this could be a result of either: (1) sex-based status differences and differential access to various proteins, (2) sex-divisions in labor which required males to find work outside of the home, which could have granted access to different foodstuffs, or (3) female abstinence from meat consumption due to fasting and religious observances, like those analyzed by Bynum (1987). Overall, slight but nonetheless statistically significant differences in $\delta^{13} \mathrm{C}$ and $\delta^{15} \mathrm{~N}$ values suggest males may have had greater access to protein resources such as meat or manured crops than their female counterparts (Nitsch, 2016).

\section{3 | METHODS}

\subsection{Analytical procedures}

Age estimation in adults was assessed using multiple indicators including degenerative changes on the pubic symphysis (Brooks \& Suchey, 1990), auricular surface changes (Lovejoy, Meindl, Pryzbeck, \& Mensforth, 1985), and when possible, morphological changes in the sternal end of ribs (İşcan et al., 1984; 1985). We used three broad, conservative age groups (18-29 years, 30-49 years, 50+ years) given the problematic estimation of precise age categories in older adults 
(Jackes, 2000). These categories were also chosen for their relation to important stages in the human life cycle, particularly in relation to reproduction, as the early age category (18-29 years) should capture the initiation of reproduction for females, and the latter categories covering the continuation of reproduction and post-reproductive age, respectively. Due to the overrepresentation of middle-aged adults and particularly low representation of older males, the middle and older age categories were collapsed for both sexes. The collapsing of these categories should still reveal insights into pregnancy-related changes with age and improves statistical analyses.

Sex was determined by utilizing standard methods of sex determination, with particular focus on pelvic (pubic bone) morphological traits including the ventral arc, sub-pubic angle, sub-pubic concavity, and the sciatic notch (Ascàdi \& Nemeskèri, 1970; Brothwell, 1981; Buikstra \& Ubelaker, 1994). When available, skulls were also analyzed for sex-related features (Buikstra \& Ubelaker, 1994) to increase accuracy of sex determination (Mays, 1998). Adult individuals with indeterminate sex due to preservation were not utilized in the present study.

A total of six dental traits were analyzed for information regarding dental lesions: antemortem tooth loss (AMTL), dental caries, tooth wear, calculus, periodontitis, and periapical lesions. All traits were examined visually and aided by diffuse lighting. Anterior (incisors and canines) and posterior dentition (premolars and molars) were analyzed separately, given the complex crown morphology of posterior dentition, particularly molars, in harboring cariogenic bacteria (Hillson, 2008).

\subsection{Antemortem tooth loss}

Teeth can be lost antemortem either as a result of: (1) advanced carious penetration of the pulp chamber which can compromise the integrity of gomphoses, (2) advanced tooth wear which can similarly expose the pulp chamber, (3) intentional ablation or removal, and (4) trauma (Lukacs, 2007). Continued eruption of teeth can also contribute to AMTL, particularly when the individual is affected by advanced gingival inflammation or periodontitis (Clarke \& Hirsche, 1991; Hildebolt \& Molnar, 1991; Varrela, Paunio, Wouters, Tiekso, \& Söder, 1995; Whittaker \& Molleson, 1996). In archaeological skeletal remains, AMTL is characterized by alveolar resorption and remodeling of alveolar sockets after the loss of a tooth (Figure 2). AMTL was calculated by scoring the number of teeth lost antemortem out of total possible or observable loci. AMTL was scored in a total of 923 female loci and 881 male loci.

\subsection{Dental caries}

Dental caries is a multifactorial infectious disease whereby the enamel surfaces of teeth are demineralized as a result of acidogenic bacteria within dental plaque (García-Godoy \& Hicks, 2008). When teeth erupt, a thin (0.1-1.0 micrometers) pellicle forms on the tooth surface to aid in lubrication for mastication as well as protection against demineralization and cariogenesis (Hara et al., 2006). Yet, dental plaque can adhere to the surface of the pellicle, containing acidogenic and aciduric bacteria such as Streptococcus and Lactobacillus species that ferment dietary carbohydrates and sucrose (Loesche, 1986; ten Cate, 2006). This fermentation produces organic acetic, lactic, formic,

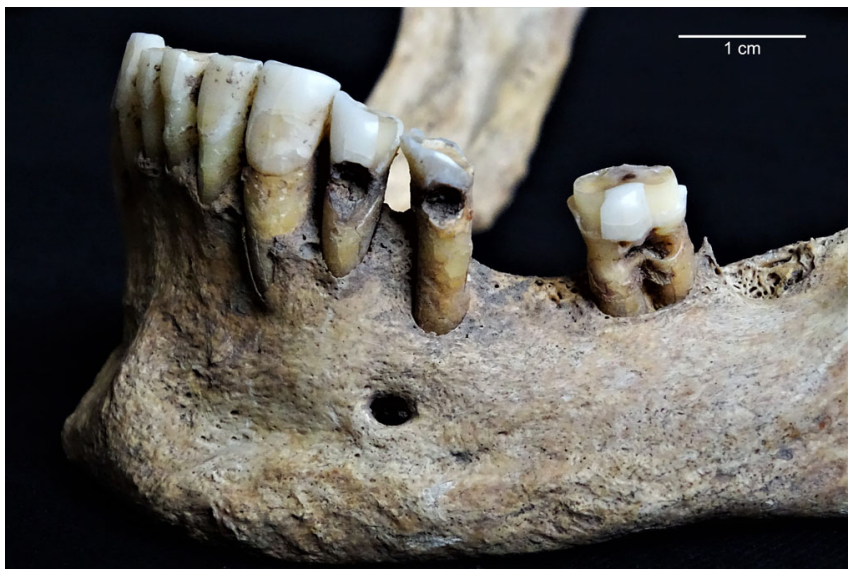

FIGURE 2 Dental caries and antemortem tooth loss observed in the mandibular dentition of HRU 4307. (Photos courtesy of Sabrina Agarwal)

and proprionic acids which create an acidic environment by reducing the resting biofilm $\mathrm{pH}$ significantly, resulting in demineralization of enamel structures and suppression of other protective non-aciduric bacteria (García-Godoy \& Hicks, 2008). Carious lesions were identified based on the presence of demineralized enamel surfaces, ranging from a localized pin prick, to complete destruction of the crown surface (Figure 2). To evaluate if carious lesions were patterned along any particular surface, the location of each observable lesion was also recorded following Buikstra and Ubelaker (1994: 55). Caries were scored in a total of 808 female teeth and 726 male teeth. We first calculated a traditional frequency of caries presence, whereby the number of teeth affected by caries are divided by the number of total teeth observed in that group. However, given the heavy amount of age-related antemortem tooth loss at Villamagna (Supplement 2), we additionally used the Caries Correction Factor developed by Lukacs (1995). This correction estimates the number of teeth lost antemortem as a result of caries which is then added to the number of observed teeth with caries before dividing by the sum of the total number of teeth observed with the total number of teeth lost antemortem:

$$
\begin{gathered}
\text { Traditional caries prevalence }=\frac{a}{n_{a}} \\
\text { Corrected caries prevalence }=\frac{(a+b x)}{\left(n_{a}+b\right)}
\end{gathered}
$$

where $a$ refers to the number of observed teeth with caries, $b$ refers to the number of teeth lost antemortem which is multiplied by proportion $x$. The proportion $x$ is obtained by comparing the number of teeth scored with carious pulp exposure versus the number of teeth scored as having non-carious pulp exposure, such as heavy wear. The sum of these products results in the total estimated number of teeth with carious lesions. This is then divided by the total number of original teeth, which is achieved by adding the total number of observed teeth $\left(n_{a}\right)$ to the total number of teeth lost antemortem $(b)$. The correction factor ultimately attempts to address the fact that many teeth that were lost antemortem may have been lost as a result of large carious lesions (Lukacs, 1995). Traditional estimates of dividing the number of observed teeth with caries by the number of total teeth thus may 
severely underrepresent actual frequencies, as a large proportion of teeth that were affected by caries and lost antemortem are never seen by the researcher. This issue is particularly compounded in samples with heavy amounts of AMTL, where observed frequencies can sometimes double when the correction factor is used (Lukacs, 1992 Lukacs, 1995). It should be noted that intentional tooth ablation can complicate the implementation of the caries correction factor, as the intentional removal of teeth can falsely mimic antemortem tooth loss. Although Robb (1997) has effectively shown that intentional tooth ablation in women was practiced in Neolithic Italy (c. 6500-3200 BC), to our knowledge, there is no known practice of intentional tooth ablation that persists through the medieval period in this region or evidence of ablation at Villamagna.

\section{4 | Tooth wear}

Tooth wear is the natural process whereby teeth progressively loose enamel and dentine as a result of mechanical contact. This contact can take place either through attrition, where teeth come into direct occlusal and incisal contact between maxillary and mandibular teeth, or via abrasion, where tooth surfaces come into contact with fibrous or coarse material, such as gritty foodstuffs (Kaidonis, 2008; Lucas, 2004). Although there have been anthropological studies on attritional wear (Kaidonis, Richards, \& Townsend, 1993), it is often difficult to differentially diagnose between attritional wear and abrasion without the use of advanced microscopy such as a scanning electron microscope (Kaidonis, 2008). As such, bioarchaeologists often examine wear as a broad mechanical process resulting from both exogenous dietary influences as well as masticatory behaviors (Larsen, 1998). Wear can influence the manifestation of carious lesions, as extreme wear can result in the exposure of the pulpal cavity and thus result in pulpitis, whereas unworn teeth can harbor cariogenic bacteria in dental surfaces such as grooves and pits. Wear was scored by both anterior (Smith, 1984) and posterior (Scott, 1979) dentition. Molar scores were averaged by tooth to allow for comparison with anterior dentition (Klaus \& Tam, 2010). Individuals who failed to have at least eight teeth were excluded. This follows the assumption that individuals who have lost more than half of their teeth likely affects later mastication patterns (Smith, 1984). Although a higher threshold is more conservative and desirable, high rates of AMTL and even postmortem tooth loss at Villamagna would have resulted in analyses of wear to a highly restricted subsample. Tooth wear was scored in a total of 25 females representing 617 teeth and 28 males representing 628 teeth. Tooth wear averages were then compared using two-tailed student's $t$-tests at the $\alpha=0.05$ level.

\section{5 | Periapical lesions}

Acute periapical lesions are cavities that form as a result of infection penetrating the pulp chamber of a tooth that then exits out of the apical foramen. Infection of the pulp chamber can be caused either as a result of carious lesions penetrating the pulp chamber, non-carious pulp exposure through significant wear, or trauma (Dias \& Tayles, 1997). If severe, infection will become pyogenic, producing a drainage of pus which leads to substantial inflammation and the formation of a

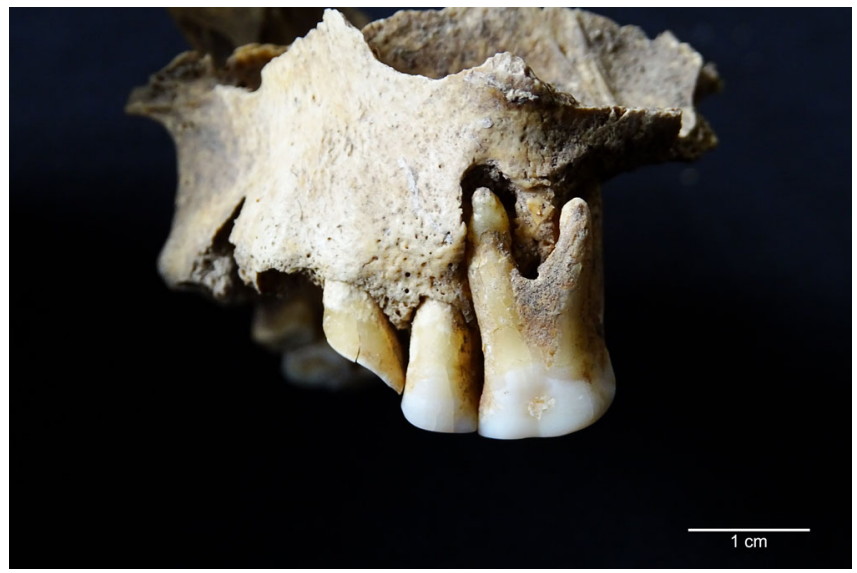

FIGURE 3 Periapical lesion on the buccal aspect of LM1 of HRU 3898. (Photos courtesy of Sabrina Agarwal)

granuloma or mass of inundated inflammatory cells. This granuloma then stimulates osteoclastic activity, which begins to resorb surrounding bone as the inflammation continues to expand (Dias \& Tayles, 1997). The result is an acute periapical lesion characterized by a cavity of resorbed bone, often on the buccal side of the alveolar bone (Hillson, 2008; Figure 3). Periapical lesions were recorded if there was a clear presence of a drainage channel accompanied by a necrotic cavity. Periapical lesions were scored as either present or absent, while simultaneously noting location and size. Periapical lesions were scored in a total of 768 female loci and 712 male loci.

\section{6 | Calculus}

Calculus, or tartar, is formed when salivary calcium-phosphate minerals naturally precipitate resulting in a partially calcified substrate that adheres to the surface of the tooth. Although incipient formation of calculus is not entirely understood, oral hygiene and the implementation of dentifrice technologies appear to severely inhibit further accretion (Jepsen, Deschner, Braun, Schwarz, \& Eberhard, 2011). White (1997), for example, suggests that supragingival calculus is relatively rare in populations that practice regular oral hygiene, with calculus usually only forming near major salivary gland ducts, such as the Stensen, Wharton, and Rivinus ducts. Conversely, populations that do not use regular dentifrice techniques or lack access to systematized oral healthcare professionals typically exhibit mild to extreme amounts of supragingival calculus and subgingival calculus, which are often strongly associated with gingival recession and periodontal disease (Jepsen et al., 2011; White, 1997). We scored calculus based on the three-stage ordinal scale by Brothwell (1981) while also noting its location on the tooth surface (Figure 4). In cases where the calculus covered multiple dental surfaces, the location was noted as "multiple." Calculus was scored in a total of 758 female teeth and 701 male teeth.

\section{7 | Periodontitis}

Periodontitis, or periodontal disease, is an advanced form of gingivitis and bacterial infection resulting in degeneration of the gingival margin (Armitage, 1995; Hernández et al., 2011). Although gingivitis is a 


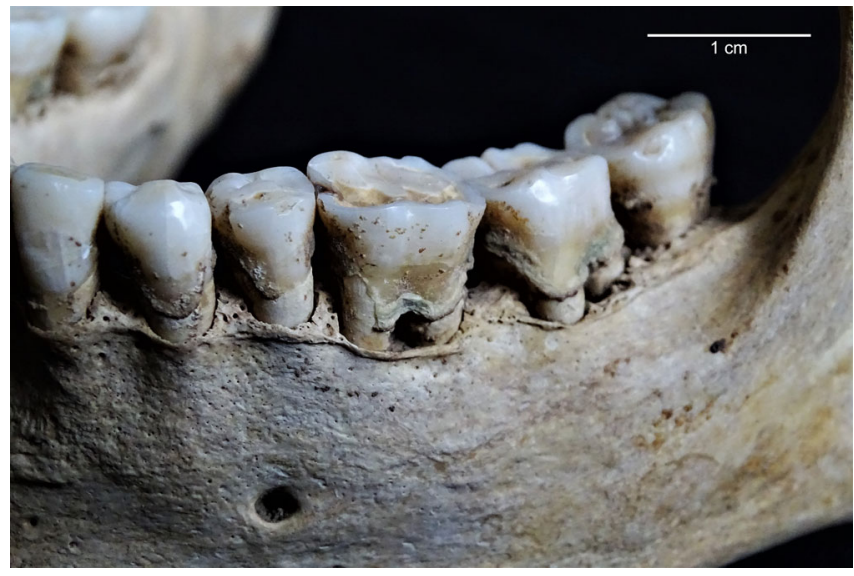

FIGURE 4 Calculus observed on the buccal aspects of the mandibular dentition of HRU 2890. Probable periodontitis as a result of interseptal inflammation and resorption of the alveolar margin. (Photos courtesy of Sabrina Agarwal)

relatively benign inflammation of the gingiva and affects adults who do not practice daily hygiene (Albandar \& Rams, 2002; Eke et al., 2015), periodontitis results in a malignant resorption and loss of irreplaceable bone that supports alveolar sockets for the dentition. Molecular studies using 16s amplicon ribosomal RNA (16s rRNA) sequences have shown that the human oral microbiome can consist up some 700 differing taxa (Aas, Paster, Stokes, Olsen, \& Dewhirst, 2005; Choi, Paster, Dewhirst, \& Göbel, 1994; Dewhirst et al., 2010; Griffen et al., 2012; Moore \& Moore, 1994; Socransky, Haffajee, Cugini, Smith, \& Kent, 1998), with over 400 of these taxa being identified in the periodontal pockets alone (Paster et al., 2001; Paster, Olsen, Aas, \& Dewhirst, 2006). Localized fluctuations of oral microflora at subgingival margins have been shown to facilitate an increase in fermentable proteins which some microbes are able to take advantage of more easily (Abusleme et al., 2013). Ecological shifts in subgingival community biomass and structure can thus send the oral biofilm into a dysbiotic state, where certain pathogenic communities such as the "red complex" (Porphyromonas gingivalis, Treponema denticola, and Tannerella forsythia) appear to play an important synergistic role with other microbes in host-culture immune system perturbations (Hajishengallis \& Lamont, 2012), ultimately resulting in excessive inflammation, weakening of periodontal ligaments, and alveolar resorption.

In skeletal samples, periodontitis is often recognized by marked porosity and exposed trabecular bone at the alveolar margin due to the resorption of the overlying alveolar bone (Clarke \& Hirsche, 1991; Kerr, 1988; Larsen, 1997). This can especially be seen in the recession of the alveolar crest relative to the cemento-enamel junction (Larsen, 1997), which has led some researchers to adopt a metric means to score periodontitis, whereby the distance between the alveolar crest and cemento-enamel junction is measured and often scored as periodontal if greater than $2 \mathrm{~mm}$ (DeWitte \& Bekvalac, 2010). However, the continued eruption of teeth throughout life (Varrela et al., 1995; Whittaker \& Molleson, 1996), particularly in response to heavy tooth wear to maintain level occlusal surfaces (Clarke \& Hirsche, 1991; Craddock \& Youngson, 2004; Hildebolt \& Molnar, 1991) suggest that the use of a $2 \mathrm{~mm}$ threshold may over estimate periodontal prevalence in skeletal samples. More detailed, ordinal severity scales have been proposed to account for these processes that mimic periodontal resorption (Costa, 1982; Kerr, 1988, 1991), although they often require relatively complete alveolar margins and are time consuming. For this study, we scored periodontal disease according to porosity or excessive (more than $2 \mathrm{~mm}$ ) distance between the CEJ-AC (Clarke \& Hirsche, 1991; Figure 4). Scores were then collapsed by individual to reflect a presence or absence of periodontitis. Overall periodontitis prevalence was calculated by dividing the observed number of individuals with periodontal disease by the total number of individuals. Periodontitis was scored in a total of 36 female individuals and 37 male individuals.

\section{8 | Fertility}

Recently, Lukacs $(2008,2012,2017)$ has argued that fertility plays an important role in the reproductive ecology model given that increased rates of fertility indicate a hormonal environment that would further increase female risk of caries and associated oral pathologies. To account for this possibility, we used fertility ratios for the late medieval period to explore possible temporal changes at Villamagna. Estimates of fertility were calculated using the $D_{30_{+}} / D_{5+}$ ratio (Buikstra \& Ubelaker, 1994) whereby the number of individuals over thirty years of age are divided by the number of individuals over five years of age. This ratio is negatively associated with birth rate, which can provide a proxy for fertility. To assess diachronic changes in fertility at Villamagna between the central and late medieval period, we used 95\% comparison intervals as outlined by Buikstra and Ubelaker (1994):

$$
95 \% \mathrm{Cl}=D_{30+} / D_{5+} \pm m_{0.05} k^{*} \infty \sqrt{\frac{0.125}{D_{5+}}}
$$

where $m$ corresponds to the value of a Studentized maximum modulus at the $\alpha=0.05$ level, $k^{*}$ as the $(N(N-1)) / 2$ for $N$ samples, with infinite $(\infty)$ degrees of freedom. These intervals are comparison rather than confidence intervals as they allow for comparisons between means without estimating parameters for true population means or proportions (see Buikstra \& Ubelaker, 1994: 534 for further discussion). Comparison intervals that fail to overlap are considered significant.

\section{9 | Statistical analyses}

Statistical analyses were carried out using primarily two-tailed $G$ tests (also known as G2 or log-likelihood ratio test) with an $\alpha=0.05$ (see Klaus \& Tam, 2010: 598 for an excellent review). This test measures goodness-of-fit by taking the log of the ratio of observed to expected counts. The equation for obtaining a $G$-statistic simplifies to $G=2$ $\sum[O \times \ln (O / E)]$, where $O$ refers to the observed number of counts, $E$ refers to the expected number of counts, and In refers to taking the natural log. Although the $G$-statistic is fit to a Chi-squared distribution $\left(\chi^{2}\right)$, the $G$-statistic differs from $\chi^{2}$ by directly dividing observed counts by expected counts, which avoids overestimating statistical differences in smaller samples when observed counts are much larger than expected counts. In the event that expected counts were too small (<5), a Fisher's Exact test with an $\alpha=0.05$ was used instead. Finally, to further explore sex-related risk for periodontitis, relative risk $(\widehat{R R})$ ratios were used using the following equation: 
TABLE 2 Sex comparison of antemortem tooth loss (AMTL) by loci

\begin{tabular}{|c|c|c|c|c|c|c|c|}
\hline Tooth type & $\begin{array}{l}\text { Female } N \\
\text { observed/total }\end{array}$ & $\begin{array}{l}\text { Female crude } \\
\text { prevalence (\% AMTL) }\end{array}$ & $\begin{array}{l}\text { Male } N \\
\text { observed/total }\end{array}$ & $\begin{array}{l}\text { Male crude } \\
\text { prevalence (\% AMTL) }\end{array}$ & G & $p$-value & Interpretation \\
\hline Incisors & $22 / 211$ & 10.43 & $13 / 195$ & 6.67 & 1.685 & 0.194 & No difference \\
\hline Canines & $3 / 114$ & 2.63 & $7 / 110$ & 6.36 & - & $0.209 * *$ & No difference \\
\hline Premolars & $21 / 240$ & 8.75 & $32 / 229$ & 13.97 & 2.844 & 0.092 & No difference \\
\hline Molars & $89 / 358$ & 24.86 & $113 / 347$ & 32.56 & 3.659 & 0.056 & No difference \\
\hline Total & $135 / 923$ & 14.63 & $165 / 881$ & 18.73 & 4.565 & $0.033^{*}$ & Significantly more AMTL in males \\
\hline
\end{tabular}

*Significant at the $a=0.05$ level.

$* * p$-value resulting from a Fisher's Exact test $(a=0.05)$ due to expected counts being less than 5.

$$
\text { Relative risk }(\widehat{R R})=\frac{P(\text { disease or outcome } \mid \text { exposure })}{P(\text { disease or outcome } \mid \text { no exposure })}
$$

The $\widehat{R R}$ estimates the risk of health event (outcome, in this case oral pathologies) within a group (exposure, in this case Females) compared to another (no exposure, Males). When the $\widehat{R R}$ is equal to 1.0, the risk is identical between groups, where a $\widehat{R R}<1.0$ indicates decreased risk in exposed group, and a $\widehat{R R}>1$ indicates increased risk for a health outcome in the exposed group relative to the not exposed group. The relative risk ratio is similar to an odds ratio (OR), except that ORs compares the odds of an event occurring compared to a non-occurrence $(a / b)$, whereas relative risk examines the probability of an event occurring by comparing the outcome of interest by all possible outcomes $(a /(a+b))$. Odds ratios approximate risk when the value of an outcome is rare or unlikely, such that $a / b \approx a /(a+b)$. When an event outcome is not rare ( $>10 \%)$, such that $a$ is not small in relation to $b$, the odds ratio can exaggerate the relationship between exposure and outcome (Ranganathan, Aggarwal, \& Pramesh, 2015). Because relative risk ratios are not normally distributed, 95\% confidence intervals were obtained by taking the log (In) of the $\widehat{R R}$ before calculating an estimated standard error $(z)$ and then transforming the resulting interval with an antilog (exp) function:

$$
\ln (\widehat{R R}) \pm z \sqrt{\frac{\left(n_{1}-x_{1}\right) / x_{1}}{n_{1}}+\frac{\left(n_{2}-x_{2}\right) / x_{2}}{n_{2}}}
$$

where $z$ corresponds to the $z$-value for a $95 \%$ confidence interval (1.96), $n$ refers to the sample group of study, and $x$ refers to the observed individuals with a given oral pathological lesion. If the confidence interval covers 1.0, the differences between exposed and not exposed groups are considered not statistically significant.

\section{4 | RESULTS}

\subsection{Antemortem tooth loss}

Both males and females showed a marked antemortem loss of posterior dentition compared to anterior dentition (Supplement 1). When AMTL was analyzed by tooth category, females only showed a higher crude prevalence of loss in incisors when compared to males, although the difference was not statistically significant (Table 2). Males showed a higher loss of canines, premolars, and molars when compared to females, although the difference was significant only when AMTL was pooled for all teeth. Both males and females showed significantly higher rates of AMTL in the older age category (30+ years) compared to the younger one (18-29 years; Supplement 2). Older males and males when pooled by age exhibited significantly more AMTL than older females and females when pooled by age (Table 3 ).

\section{2 | Caries}

Caries frequencies within sexes showed that both males and females had significantly more posterior dental caries than anterior caries (Supplement 1). Males exhibited a significantly higher prevalence of posterior caries when compared to females (Table 4). When caries were compared by sex in terms of dental surface location, only root caries were found to be significantly different between the sexes $(G=$ 4.27, $p=0.03$ ), with males (10.69\%) exhibiting more than their female counterparts (4.05\%). When caries were analyzed by age and sex, both corrected and uncorrected estimates showed that caries were more prevalent in the older age category (30+ years) for both sexes (Supplement 2). Yet, although uncorrected caries showed no significant sex difference for either age group, the older male category and pooled male dentition showed a significantly higher prevalence of caries compared to older females and pooled female dentition when using corrected estimates (Table 3).

\section{3 | Tooth wear}

Both females and males exhibited significantly increased tooth wear with age in both anterior and posterior dentition (Supplement 3). When sexes were compared, males displayed significantly higher wear averages in younger age, where females only showed significantly higher wear estimates in older age in the posterior dentition (Table 5).

\section{4 | Calculus}

Calculus patterning throughout the oral cavity showed overall higher prevalence in anterior dentition for both sexes, although this was only significant for males (Supplement 1). Calculus was more prevalent in the older age category for both sexes (Supplement 2). When anterior and posterior dentition was pooled and compared by sex and age, males exhibited higher prevalence of calculus than females, although the difference was not significant (Table 3). 
TABLE 3 Sex and age comparisons of dental pathological lesions

\begin{tabular}{|c|c|c|c|c|c|c|c|c|}
\hline Analysis & Age category & $\begin{array}{l}\text { Female } N \\
\text { observed/ } \\
\text { total }\end{array}$ & $\begin{array}{l}\text { Female } \\
\text { crude } \\
\text { prevalence }\end{array}$ & $\begin{array}{l}\text { Male N } \\
\text { observed/ } \\
\text { total }\end{array}$ & $\begin{array}{l}\text { Male } \\
\text { crude } \\
\text { prevalence }\end{array}$ & G & $p$-value & Interpretation \\
\hline \multirow[t]{3}{*}{$\mathrm{AMTL}^{\mathrm{a}}$} & $18-29$ years & $6 / 245$ & 2.45 & $7 / 223$ & 3.14 & 0.202 & 0.653 & No difference \\
\hline & $30+$ years & $129 / 678$ & 19.03 & $158 / 658$ & 24.01 & 3.915 & $0.048 *$ & Significantly more AMTL in males \\
\hline & Total & $135 / 923$ & 14.63 & $165 / 881$ & 18.73 & 4.369 & $0.037 *$ & Significantly more AMTL in males \\
\hline \multirow[t]{6}{*}{ Caries $^{b}$} & $18-29$ years uncorrected & $27 / 241$ & 11.20 & $28 / 217$ & 12.90 & 0.027 & 0.601 & No difference \\
\hline & $30+$ years uncorrected & $121 / 576$ & 21.34 & $131 / 509$ & 25.74 & 2.209 & 0.137 & No difference \\
\hline & Total uncorrected & $148 / 808$ & 18.32 & $159 / 726$ & 21.90 & 2.452 & 0.117 & No difference \\
\hline & $18-29$ years corrected & $32 / 247$ & 12.96 & $34 / 224$ & 14.18 & 0.413 & 0.520 & No difference \\
\hline & $30+$ years corrected & $233 / 696$ & 33.48 & $275 / 674$ & 40.65 & 4.957 & $0.026 *$ & $\begin{array}{l}\text { Significantly more caries in older } \\
\text { males }\end{array}$ \\
\hline & Total corrected & $265 / 943$ & 28.10 & $309 / 898$ & 34.41 & 5.873 & $0.015 *$ & Significantly more caries in males \\
\hline \multirow[t]{3}{*}{ Calculus $^{c}$} & $18-29$ years & $112 / 218$ & 51.38 & $113 / 213$ & 53.05 & 0.058 & 0.809 & No difference \\
\hline & $30+$ years & $374 / 540$ & 69.26 & $331 / 488$ & 73.88 & 0.077 & 0.782 & No difference \\
\hline & Total & $486 / 758$ & 64.12 & $444 / 701$ & 63.34 & 0.035 & 0.853 & No difference \\
\hline \multirow{3}{*}{$\begin{array}{l}\text { Periapical } \\
\text { lesions }^{d}\end{array}$} & $18-29$ years & $4 / 241$ & 1.66 & $5 / 219$ & 2.28 & - & $0.742 * *$ & No difference \\
\hline & $30+$ years & $21 / 527$ & 3.98 & $11 / 493$ & 2.23 & 2.55 & 0.110 & No difference \\
\hline & Total & $25 / 768$ & 3.26 & $16 / 712$ & 2.25 & 1.37 & 0.243 & No difference \\
\hline
\end{tabular}

$\mathrm{AMTL}=$ antemortem tooth loss.

aNumber of discernable teeth lost antemortem/number of observable loci.

${ }^{b}$ Number of observed and/or estimated carious lesions/total number of teeth observed. See text for details on calculating corrected vs. uncorrected prevalence.

cNumber of observed teeth with calculus/total number of teeth observed.

${ }^{\mathrm{d}}$ Number of discernable loci with periapical lesions/total number of observable loci.

*Significant at the $\mathrm{a}=0.05$ level.

$* * p$-value resulting from a Fisher's Exact test $(\mathrm{a}=0.05)$ due to expected counts being less than 5 .

\section{5 | Periapical lesions}

Both males and females showed higher prevalence of periapical lesions in the older age category, although the differences were not significant (Supplement 2). When sexes were compared, females showed an overall higher prevalence of periapical lesions than males, although the difference was not significant (Table 3).

\section{6 | Periodontitis}

Relative risk ratios demonstrated that males were at an increased risk for periodontitis than females for both age groups and overall, although differences were not significant (Table 6)

\section{7 | Fertility}

$D_{30+} / D_{5+}$ fertility estimates suggest a slight increase in fertility from the central medieval $(0.372)$ to the late medieval period (0.342), although this difference is not significant (Table 7). The relevance of the fertility estimates calculated here are discussed below.

\section{5 | DISCUSSION}

\section{1 | Diet, reproductive ecology, and oral health at Villamagna}

Significant age-related changes in AMTL, caries, tooth wear, and calculus were found in both sexes. Due to the fact that cariogenesis is an age-progressive process, it follows that older individuals will have higher prevalence of caries due to increased exposure to aciduric and acidogenic oral bacteria (Hillson, 2000, 2001). Significant AMTL (males $=25.17 \%$; females $=18.39 \%$ ) and caries (males $=33.18 \%$; females $=$ $26.34 \%$ ) observed in the posterior dentition for both sexes is similarly not surprising, given the complex crown morphology of posterior teeth, larger occlusal surfaces, and grooves that harbor cariogenic bacteria (Hillson, 2008). Higher levels of calculus in older males (73.88\%) and females (69.26\%) may similarly suggest elevated levels of agerelated microbial oral flora forming dental plaque as a result of increased carbohydrate consumption (Hillson, 2008). Higher averages of wear in older age for both sexes are similarly not surprising given the age-progressive process of mastication (Lovejoy, 1985; Powell, 1985; Scott, 1979; Smith, 1984). However, sex differences in wear

TABLE 4 Sex-comparison of anterior and posterior caries

\begin{tabular}{|c|c|c|c|c|c|c|c|}
\hline Location & $\begin{array}{l}\text { Female } N \\
\text { observed/total }\end{array}$ & $\begin{array}{l}\text { Crude female } \\
\text { prevalence ( } \% \text { affected) }\end{array}$ & $\begin{array}{l}\text { Males } N \\
\text { observed/total }\end{array}$ & $\begin{array}{l}\text { Crude male } \\
\text { prevalence ( } \% \text { affected) }\end{array}$ & G & $p$-value & Interpretation \\
\hline Anterior & $15 / 303$ & 4.95 & $17 / 298$ & 5.70 & 0.16 & 0.689 & No difference \\
\hline Posterior & $133 / 505$ & 26.34 & $142 / 428$ & 33.18 & 3.664 & $0.056 *$ & More posterior caries in males \\
\hline
\end{tabular}

*Significant at the $\mathrm{a}=0.05$ level. 
TABLE 5 Sex-related tooth wear by age

\begin{tabular}{|c|c|c|c|c|c|c|c|c|}
\hline Age (years) & $\begin{array}{l}\text { Female anterior } \\
\text { tooth wear average }\end{array}$ & $\begin{array}{l}\text { Male anterior } \\
\text { tooth wear average }\end{array}$ & $t$ & $p$-value & $\begin{array}{l}\text { Female posterior } \\
\text { tooth wear average }\end{array}$ & $\begin{array}{l}\text { Male posterior } \\
\text { tooth wear average }\end{array}$ & $t$ & $p$-value \\
\hline $18-29$ & 4.89 & 5.65 & -3.24 & $0.001 *$ & 2.98 & 3.6 & -2.701 & $0.007 *$ \\
\hline $30+$ & 5.65 & 7.19 & -1.47 & 0.144 & 5.65 & 5.03 & 3.312 & $0.001 *$ \\
\hline Total & 6.20 & 6.75 & -2.98 & $0.003 *$ & 4.79 & 4.52 & 1.611 & 0.108 \\
\hline
\end{tabular}

*Significant at the $a=0.05$ level.

are worth considering. Significantly higher averages of wear in younger males throughout the oral cavity (anterior $=5.65$; posterior $=3.6$ ) may suggest increased dietary reliance on coarse cultigens in younger age as compared to females (anterior $=4.89$; posterior $=2.98$ ). In older age, females exhibit more posterior wear averages (5.65) than males (5.03), although this could be a function of older males having increased posterior AMTL, leaving females with higher wear averages in posterior dentition.

Another possibility is that wear differences may reflect gendered and age-related dietary changes throughout the life course, with females having increased reliance on coarse starchy cultigens in later life. This would support previous isotopic evidence showing females having lower $\delta^{15} \mathrm{~N}$ and $\delta^{13} \mathrm{C}$ values than males, overall indicating a higher reliance on carbohydrate resources such as starchy cultigens in females compared to males (Nitsch, 2016). Although this likely suggests increased access to dietary protein sources such as terrestrial faunal and marine resources in younger males, higher wear averages in younger age males throughout the oral cavity could also suggest increased reliance on manured crops, which would explain higher $\delta^{15} \mathrm{~N}$ values as well as higher wear averages compared to females. The process of manuring on cereals has been shown experimentally to impact $\delta^{15} \mathrm{~N}$ levels extracted from human bone collagen, resulting in trophic enrichment of $\delta^{15} \mathrm{~N}$ and suggesting that communities which rely heavily on manured cereal grains may exhibit higher $\delta^{15} \mathrm{~N}$ values that could be mistakenly be interpreted as a result of animal consumption (Bogaard, Heaton, Poulton, \& Merbach, 2007; Fraser et al., 2011). Manuring, as well as marling-fertilizing with a mixture of clays, calcium, and lime carbonates-were both techniques commonly used throughout medieval agrarian settings, particularly in relation to demesne lands (Jones, 2004; Mathew, 1993). Although marl could potentially influence wear patterns via coarse inclusions within dietary produce, it is unlikely that it would be readily incorporated into the diet given that food processing likely removed fertilized soil and marl before cooking,

TABLE 6 Relative risk (RR) ratios comparison of periodontitis by sex and age

\begin{tabular}{lcccl} 
Age (years) & $\begin{array}{l}\text { Female } \\
\text { present/absent }\end{array}$ & $\begin{array}{l}\text { Male } \\
\text { present/absent }\end{array}$ & $\mathbf{R R}^{\mathbf{a}}$ & $\mathbf{9 5 \% \mathrm { Cl } ^ { \mathbf { b } }}$ \\
\hline $18-29$ & $6 / 3$ & $9 / 1$ & 0.80 & $0.50-1.28$ \\
\hline $30+$ & $24 / 3$ & $27 / 0$ & 0.91 & $0.81-1.01$ \\
\hline Total & $30 / 6$ & $36 / 1$ & 0.88 & $0.76-1.01$ \\
\hline
\end{tabular}

${ }^{a} R R$ ratio results. Greater prevalence in females if $R R \geq 1.01$; greater prevalence in males if $R R \leq 0.99$.

b $95 \%$ confidence intervals $(\mathrm{Cl})$ for each RR ratio. First number reported is the lower interval, where second number reported is upper bound interval. Note that when the confidence interval covers 1.0, there is no significant difference. although future research is needed to confirm this. Thus, young males in particular may have had a more varied plant-animal diet by incorporating manured crops, although further analyses using isotopic analyses throughout the life course by sampling throughout different skeletal elements as well as further archaeobotanical evidence are required to confirm this.

The overall lack of statistically significant differences between males and females for AMTL and caries was surprising. In both bioarchaeological (Cucina \& Tiesler, 2003; Nelson, Lukacs, \& Yule, 1999; Oyamada et al., 2007; Watson et al., 2010) and clinical studies (Al-Shammery, El-Backly, \& Guile, 1998; Corraini et al., 2009; López \& Baelum, 2006; Shigli, Hebbal, \& Angadi, 2009), higher rates of AMTL have consistently been observed in females than males. Some clinical research suggests that AMTL is more likely a result of carious pulp exposure in females (Meisel et al., 2008; Shigli et al., 2009), where AMTL in males is more likely a result of periodontal disease (Anand \& Kuriakose, 2009; Wasterlain, Cunha, \& Hillson, 2011). Females at Villamagna did show a higher prevalence of caries that penetrated the pulp chamber (20.27\%) than males (16.98\%), although the difference was not significant. Nevertheless, this paired with the results that males exhibited higher prevalence of periodontal disease $(\widehat{R R}=0.88)$, may support these biomedical observances.

Corrected and uncorrected estimations of caries frequencies only showed intra-sex differences in caries prevalence by older age and in lesion location throughout the oral cavity, but no significant differences between sexes. In both uncorrected (males = 25.74\%; females $=21.34 \%$ ) and corrected (males $=40.65 \%$; females $=$ $33.48 \%$ ) estimates, males exhibited higher caries prevalence than females, but only reached significance in corrected older males and when ages were pooled (Table 3). A wealth of clinical studies examining sex differences in caries prevalence in children have found girls and boys to have no difference in caries experience (Birkeland, Ibrahim, Ghandour, \& Haugejorden, 2005; Campus, Lumbau, Lai, Solinas, \& Castiglia, 2001; Perinetti, Caputi, \& Varvara, 2005; Sgan-Cohen, Katz, Horev, Dinte, \& Eldad, 2000; Suni, Helenius, \& Alanen, 1998; Younes \& El-Angbawi, 1982) or boys having higher prevalence than girls (Freeman, Maizels, Wyllie, \& Sheiham, 1993; Leroy, Bogaerts, Lesaffre, \& Declerck, 2005; Sales-Peres \& Bastos, 2002). These studies interpret caries experienced in light of socio-

TABLE 7 Fertility estimates by phase for Villamagna

$\begin{array}{lllll}\text { Phase } & \text { Dates } & D_{30+} / D_{5+} & \text { Lower 95\% Cl } & \text { Upper 95\% Cl } \\ \text { Central } & \text { 10th to 13th c. } & 0.37 & 0.28 & 0.47 \\ \text { Late } & \text { 13th to 14th c. } & 0.34 & 0.29 & 0.39\end{array}$

$\mathrm{Cl}=$ confidence interval . 
economic factors such as diet, access to oral healthcare, ora hygiene procedures, and dental behaviors. These studies are not incompatible with the reproductive ecology model, yet the observation that females at Villamagna did not overtake male caries prevalence in the older age group is surprising given the overrepresentation of older (50+ years) females in this age category. Overrepresentation of older females compared to males would suggest increased risk for caries as a result of parity-related exposure to elevated hormone levels that have deleterious effects on salivary chemistry and flow.

This is further complicated by the fertility estimates at Villamagna. Although not significant, fertility estimated from $D_{30_{+}} / D_{5_{+}}$ratios demonstrated a slight increase in fertility by the late medieval period (central $=0.37$, late $=0.34$ ). This supports previous paleodemographic work on Villamagna conducted by Candilio and Cox (2016). Using $p$ ratios alongside a large meta-analysis of central medieval Italian cemeteries (Barbiera \& Dalla Zuanna 2009), Candilio and Cox found that both central and late medieval Villamagna fell within the upper limits of Italian comparisons, indicating high mortality, low life expectancy, and likely high fertility for central and late medieval Villamagna (Candilio \& Cox, 2016). Under the reproductive ecology model, such high estimates would imply higher estimations of caries prevalence in females, which was not observed. Although it would be ideal to calculate $D_{1-10} / D_{1-5}$ ratios to determine whether temporal changes in birth rate were accompanied by weaning related deaths, under-representation of infant remains in the Central Medieval period $(n=7)$ prevented such analyses. Overall estimates for both Central and Late Medieval periods were relatively high, and given the possibility of increased fertility during this time period, we would expect to see a starker difference between male and female caries prevalence.

The relationship between tooth wear and caries at Villamagna is worth considering further. Although excessive wear can lead to perforation of the pulp chamber and resulting caries or periapical lesions, teeth with little to no wear are often more susceptible to surface caries due to the preservation of grooves and pits on enamel surfaces which can harbor cariogenic bacteria (Hillson, 2008; Klaus \& Tam, 2010). At Villamagna, the higher rate of wear observed in older female posterior dentition probably explains the increased pulpal perforations and periapical lesions in females despite differences not being significant. However, a higher average rate of wear throughout younger male oral cavities, paired with lack of dental trauma and higher rates of older male AMTL and male periodontitis, likely all could point to males having a heavier reliance on coarse and textured foodstuffs in early life that resulted in heavily abraded wear, pulpal perforation, and AMTL in later life. Such dietary influences in early life may suggest the patterning of dental caries observed in later life, with minimal sex differences or with males even having increased caries prevalence when compared to females in corrected estimates.

Results demonstrating a higher prevalence of root caries among males (males $=10.69 \%$; females $=4.05 \%$ ) is also worth considering further. A study by Watson and colleagues (Watson et al., 2010) examining bioarchaeological remains from Early Agricultural period (1600 B.C. to A.D. 200) Mexico showed females having a higher prevalence of root caries when compared to their male counterparts. Drawing in part on clinical literature, the authors suggest that the higher prevalence of sub-cervical caries in females was likely a result of increased resorption of the alveolar margin which exposed the roots to cariogenic activity (Watson et al., 2010). However, a bioarchaeological study conducted on skeletal remains from Lagoa Santa, southern Brazil found contrary results, with males exhibiting more root caries than females, although the difference was not significant (DaGloria \& Larsen, 2014). Cervical and sub-cervical caries are highly linked to the recession of alveolar margins and periodontal disease (Hillson, 2008; Otani et al., 2009), and given that males exhibited slightly more periodontal disease at Villamagna (Table 6), it follows that they would exhibit more cervical caries than females.

Under the reproductive ecology model, the earlier eruption of teeth in females may help to explain their higher prevalence of caries. In short, the female dentition is exposed to oral flora earlier and longer than males, thus exposing their teeth to higher risk of cariogenesis (DePaola, Soparker, Tavares, Allukian, \& Peterson, 1982). The higher prevalence of male caries in the younger age group we observed in both corrected $($ males $=14.18 \%$, females $=12.96 \%)$ and uncorrected (males $=12.90 \%$, females $=11.20 \%$ ) estimates challenges this idea and suggests that exposure time is not a strong predictor of carious lesion patterning (Moorrees, 1957). Another potential factor put forth by the reproductive ecology model is that salivary chemistry is altered significantly in episodes of fasting, which ultimately exposes females to higher risk of caries (Lukacs, 2012). In a clinical study by Johansson, Ericson, and Steen (1984), the effect of fasting on women was found to produce reduced salivary flow and increased plaque formation. Although the study controlled for diet over an 8-day period, the statistical power of the study is relatively low given the final sample of only eight women able to complete the full fasting period. Nevertheless, results from this study suggest that in the context of Villamagna, given the significantly lower values of $\delta^{15} \mathrm{~N}$ and $\delta^{13} \mathrm{C}$ in females (Nitsch, 2016), which might be associated with fasting, we would expect females to show a higher prevalence of caries than were observed under the reproductive ecological model. In the later middle ages, in relation to new ideas about religious communities and individual devotion, a number of women in Italy and elsewhere undertook extreme fasting (Bell, 1987; Bynum, 1987). In the 13th to 16th centuries, women seem to have concentrated greater attention than men to food and abstinence from food (whether all food or different kinds of food, such as meat) within their religious practice (Bynum, 1985; Newman 1995).

The most parsimonious explanation under the reproductive ecology model posits that pregnancy-related hormone changes in salivary production and quality ultimately result in higher caries prevalence amongst females (Lukacs, 2017; Lukacs \& Largaespada, 2006). However, clinical salivary literature illustrates the complicated role that saliva plays in relation to oral pathologies. Age-related changes to salivary production have been observed in both males and females, suggesting lower resting saliometric profiles in the elderly for both sexes, although with females having lower salivary flow rates than males (Navazesh, Mulligan, Kipnis, Denny, \& Denny, 1992; Pedersen et al., 1985; Percival, Challacombe, \& Marsh, 1994; Sreebny, 2000). However, inconsistencies in methodologies and the impact of medicinal side effects in the elderly prevent simple assessments of how ageing affects salivary production (Dodds, Johnson, \& Yeh, 2005; Navazesh \& Kumar, 2008; Sreebny, 2000). For instance, saliometric profiles vary substantially with stimulation. Resting 
(i.e., unstimulated) salivary flows are comprised of $70 \%$ input from the submandibular/sublingual glands, 15-20\% from the parotid gland, and $5-8 \%$ from minor salivary glands (Sreebny, 2000). Stimulation alters where salivary production originates, with upwards of $40-50 \%$ from the parotid and sub-mandibular and sub-lingual glands (Sreebny, 2000). Rigorous studies not only measure stimulated and unstimulated salivary flows but also measure glandular saliva (Navazesh \& Kumar, 2008). In a large $(n=1,130)$ cohort study of non-medicated individuals, Dodds et al. (2005) collected saliva using these measurements alongside the compositional analysis of saliochemical profiles for each individual. The authors found that salivary production and flow declined with age in all secretions except for unstimulated parotid flow, with females exhibiting lower flow rates than males (Dodds et al., 2005). In an experimental study examining salivary flow rates between premenopausal, perimenopausal, and postmenopausal women, results showed that only submandibular salivary production was significantly different between pre- and postmenopausal women (Streckfus et al., 1998). Overall reduction in sub-mandibular salivary secretion could have impacts on caries manifestations, as sub-mandibular glands are responsible for producing organic glycoproteins in the form of mucins, which are important in preventing demineralization and plaque formation (Amerongen, Oderkerk, \& Driessen, 1987; Baughan, Robertello, Sarrett, Denny, \& Denny, 2000; Slomiany, Murty, Piotrowski, \& Slomiany, 1996; Tabak, Levine, Mandel, \& Ellison, 1982; Vissink, Spijkervet, \& Van Nieuw Amerongen, 1996). Pregnancy has also been shown to result in a decrease in salivary calcium and phosphate which aid in remineralizing enamel (Laine, 2002). Overall, the role of saliva in the manifestation of oral pathologies is a crucial one and should not be overlooked.

Another factor that has not been fully addressed in bioarchaeological analyses is the aforementioned interplay between salivary secretion and mastication. Previous research has shown that masticatory performance decreases with tooth loss, particularly in post-canine teeth (Akeel, Nilner, \& Nilner, 1992; Hatch, Shinkai, Sakai, Rugh, \& Paunovich, 2000; Julien, Buschang, Throckmorton, \& Dechow, 1996; Van der Bilt, Oltohoff, Bosman, \& Oosterhaven, 1994). Given that males exhibited significantly more posterior AMTL than females (males $=25.17 \%$; females $=18.39 \% ; p=0.001$ ), and more overall AMTL in both the older age category (males $=24.01 \%$, females $=19.03 \% ; p=0.048$ ) and when pooled by age (males $=$ $18.73 \%$, females $=14.63 \% ; p=0.037$ ), this could suggest that older males may have had reduced masticatory performance as a result of tooth loss. This reduction in bite force and total occlusal area would likely result in reduced masticatory-parotid salivary reflex, which can cascade into reduced salivary flow and quality and increased risk of cariogenesis. Furthermore, females at Villamagna were observed to have higher wear averages in older age, and lower $\delta^{15} \mathrm{~N}$ and $\delta^{13} \mathrm{C}$ values compared to males, although males exhibited more corrected caries in older age and when pooled. Taken together, older female reliance on plant-based foodstuffs with firm consistency could have resulted in more wear, but been adaptive in that the mechanical demands of mastication for such cultigens could have resulted in salivary hyperfunction and thus buffering from caries (Dodds \& Johnson, 1993; Ikebe et al., 2007; Navazesh \& Kumar, 2008; Yeh et al., 2000). Future research in needed to explore this possible relationship further, possibly by analyzing dental microwear as well as marking masticatory entheseal changes in relation to carious lesions.

Recent clinical research on the relationship between early childhood malnutrition and oral pathologies in adult permanent dentition suggests additional factors which may have affected the medieval population at Villamagna (Deeley et al., 2008; Patir et al., 2008; Psoter et al., 2008b; Psoter, Gebrian, Prophete, Reid, \& Katz, 2008a; Psoter, Reid, \& Katz, 2005; Reyes-Perez et al., 2014; Russell, Psoter, JeanCharles, Prophte, \& Gebrian, 2010). A number of recent studies suggest that stress, particularly early childhood protein-energy malnutrition (ECPEM) during growth and development, can have severe consequences on both primary (Alvarez et al., 1988; Alvarez, Eguren, Caceda, \& Navia, 1990; Cleaton-Jones et al., 2000; Infante \& Gillespie, 1976, 1977; Kanchanakamol et al., 1996; Li, Navia, \& Bian, 1996; Sweeney \& Guzman, 1966; Sweeney, Saffir, \& De Leon, 1971) and permanent dentition, including eruption (Psoter et al., 2008a), periodontal disease (Russell et al., 2010), caries (Psoter et al., 2005; Reyes-Perez et al., 2014), and salivary gland hypofunction (Psoter et al., 2008b). A number of epidemiological studies have found associations between enamel hypoplasias (Infante \& Gillespie, 1976, 1977; Kanchanakamol et al., 1996; Li et al., 1996; Pascoe \& Seow, 1994; Sweeney et al., 1971; Sweeney \& Guzman, 1966), and wasting and stunting (Alvarez, 1995; Alvarez et al., 1988, 1990; Cleaton-Jones et al., 2000; Li et al., 1996) with caries incidence in primary and permanent teeth (Alvarez, 1995; Psoter et al., 2005), suggesting the importance of growth and development in caries incidence throughout the life course. Although bioarchaeologists have been keen to examine oral pathologies in relation to age-at-death and frailty (DeWitte \& Bekvalac, 2010), the inverse link between early childhood stress and the manifestation of oral pathologies in later life has not been fully explored in bioarchaeological studies and provides a potentially exciting avenue for further research.

In summary, given that we see: (1) significantly higher prevalence of AMTL and caries in older males; (2) previous isotopic evidence suggesting males had higher access to more protein-rich resources where females showed significantly lower $\delta^{15} \mathrm{~N}$ and $\delta^{13} \mathrm{C}$ values, suggesting an increased reliance on starchy cultigens; and (3) overrepresentation of $50+$ year old females in comparison to males, we would expect to discover starker sex differences in the patterning of female oral pathological lesions under the reproductive ecology model. We suggest that our results are better explained by the dietary model. Although the dietary model is more compelling in this context, we also find that the observed results at Villamagna may best be explained by a synthesis of dietary and salivary factors. For example, given the fact that females at Villamagna likely consumed higher quantities of starchy foods compared to males, we would expect higher caries prevalence in females from the perspective of the dietary model. We suggest that salivary factors relating to food texture and alimentary stimulation, as well as food preparation techniques may act as buffers to cariogenesis and overall caries prevalence, even in the consumption of cariogenic foods (lkebe et al., 2007; Yeh et al., 2000). Observed patterns of increased male oral pathological lesions likely indicate trade-offs throughout the life course, whereby age-related changes in diet might have affected overall oral health in older males. Similarly for females, changes in diet throughout the life course may have 
affected masticatory patterns and oral ecology that could have paradoxically buffered against oral pathological lesions in later life.

\section{6 | CONCLUSION}

The manifestation of oral pathological lesions and caries in particular remains a complicated and exciting field of bioarchaeological inquiry Tracing proximate and ultimate explanations for oral health require the employment of multiple methodologies throughout the oral cavity alongside biocultural context and supplementation of emerging etiologies in clinical studies. Both reproductive and dietary explanations contribute immensely to the complex etiology of cariogenesis. However, the opposition of such models should be met with caution, as carious lesions may best be understood as the complicated intersection of saliometric and saliochemical profiles, age-related changes in diet, mechanical factors relating to mastication and salivary reflexes, and even growth and development. This is further complicated by the fact that both diet and reproductive ecology are age-related processes that alter and fluctuate throughout the life course. Future work should also consider corroboration with biocultural information gleaned from historical documents as well as archaeobotanical and isotopic methodologies relating to diet, food preparation, and possibly even food texture.

\section{ACKNOWLEDGMENTS}

This research was supported by the University of Michigan, Dearborn's Rackham grant (P.B.), and the University of California, Berkeley's Archaeological Research Facility Stahl Faculty grant (S.C.A). The authors also extend their sincere thanks to Dr. Elizabeth Fentress for welcoming collaboration on the Villamagna archaeological project. The authors would also like to acknowledge Katie Kinkopf for her collaboration throughout the project, as well as Ali Slonina, Gabriella Calvaruso, and Francesco la Pastina for their assistance at Sapienza University. Finally, we thank the reviewer and editor for their detailed comments and suggestions.

\section{ORCID}

Trent M. Trombley (D) https://orcid.org/0000-0003-0474-4800 Sabrina C. Agarwal (D) https://orcid.org/0000-0003-0543-0053 Patrick D. Beauchesne (D) https://orcid.org/0000-0002-5800-9732

\section{REFERENCES}

Aas, J. A., Paster, B. J., Stokes, L. N., Olsen, I., \& Dewhirst, F. E. (2005). Defining the normal bacterial flora of the oral cavity. Journal of Clinical Microbiology, 43(11), 5721-5732.

Abusleme, L., Dupuy, A. K., Dutzan, N., Silva, N., Burleson, J. A., Strausbaugh, L. D., ... Diaz, P. I. (2013). The subgingival microbiome in health and periodontitis and its relationship with community biomass and inflammation. Multidisciplinary Journal of Microbial Ecology, 7(5), 1016-1025.

Agrawal, K. R., Lucas, P. W., Bruce, I. C., \& Prinz, J. F. (1998). Food properties that influence neuromuscular activity during human mastication. Journal of Dental Research, 77, 1931-1938.

Akeel, R., Nilner, M., \& Nilner, K. (1992). Masticatory efficiency in individuals with natural dentition. Swedish Dental Journal, 16, 191-198.
Albandar, J. M., \& Rams, T. E. (2002). Global epidemiology of periodontal diseases: An overview. Periodontology, 2000(29), 7-10.

de Almeida, P. D. V., Grégio, A. M. T., Machado, M. A. N., de Lima, A. A. S., \& Azevedo, L. R. (2008). Saliva composition and functions: A comprehensive review. Journal of Contemporary Dental Practice, 9(3), 72-80.

Al-Shammery, A., El-Backly, M., \& Guile, E. E. (1998). Permanent tooth loss among adults and children in Saudi Arabia. Community Dental Health, $15,277-280$.

Alvarez, J. O. (1995). Nutrition, tooth development, and dental caries. American Journal of Clinical, Nutrition, 61(2), 410S-416S.

Alvarez, J. O., Lewis, C. A., Saman, C., Caceda, J., Montalvo, J., Figueroa, M. L., ... Navia, J. M. (1988). Chronic malnutrition, dental caries, and tooth exfoliation in Peruvian children aged 3-9 years. American Journal of Clinical Nutrition, 48(2), 368-372.

Alvarez, J. O., Eguren, J. C., Caceda, J., \& Navia, J. M. (1990). The effect of nutritional status on the age distribution of dental caries in the primary teeth. Journal of Dental Research, 69(9), 1564-1566.

Amerongen, A. V. N., \& Veerman, E. C. I. (2002). Saliva - the defender of the oral cavity. Oral Diseases, 8(1), 12-22.

Amerongen, A. V. N., Oderkerk, C. H., \& Driessen, A. A. (1987). Role of Mucins from human whole saliva in the protection of tooth enamel against demineralization in vitro. Caries Research, 21(4), 297-309.

Anand, P. S., \& Kuriakose, S. (2009). Causes and patterns of loss of permanent teeth among patients attending a dental teaching institution in south India. Journal of Contemporary Dental Practice, 10(5), 57-64.

Anderson, D. J., \& Hector, M. P. (1987). Periodontal mechanoreceptors and parotid secretion in animals and man. Journal of Dental Research, 66, 518-523.

Anderson, D. J., Hector, M. P., \& Linden, R. W. A. (1996). The effects of unilateral and bilateral chewing, empty clenching and simulated bruxism, on the masticatory-parotid salivary reflex in man. Experimental Physiology, 81, 305-312.

Arantes, R., Santos, R. V., Frazao, P., \& Coimbra, C. E. A. (2009). Caries, gender and socio-economic change in the Xavante Indians from Central Brazil. Annals of Human Biology, 36(2), 162-175.

Armitage, G. C. (1995). Clinical evaluation of periodontal diseases. Periodontology, 2000(7), 39-53.

Ascàdi, G., \& Nemeskèri, J. (1970). History of human life-span and mortality. Budapest: Akàdemiai Kiadò.

Barbiera, I., \& Dalla-Zuanna, G. (2009). Population dynamics in Italy and in the middle ages: New insights from archaeological findings. Population and Development Review, 35(2), 367-389.

Baughan, L. W., Robertello, F. J., Sarrett, D. C., Denny, P. A., \& Denny, P. C. (2000). Salivary mucin as related to oral Streptococcus mutans in elderly people. Oral Microbiology and Immunology, 15(1), 10-14.

Bell, R. (1987). Holy anorexia. Chicago: University of Chicago Press.

Birkeland, J. M., Ibrahim, Y. E., Ghandour, I. A., \& Haugejorden, O. (2005). Severity of dental caries among 12-year-old Sudanese children with different fluoride exposure. Clinical Oral Investigations, 9(1), 46-51.

Bishop, B., Plesh, O., \& McCall, W. D. (1990). Effects of chewing frequency and bolus hardness on human incisor trajectory and masseter muscle activity. Archives of Oral Biology, 35, 311-318.

Bogaard, A., Heaton, T. H. E., Poulton, P., \& Merbach, I. (2007). The impact of manuring on nitrogen isotope ratios in cereals: archaeological implications for reconstruction of diet and crop management practices. Journal of Archaeological Science, 34(3), 335-343.

Bots, C. P., Brand, H. S., Veerman, E. C. I., van Amerongen, B. M., \& Nieuw Amerongen, A. V. (2004). Preferences and saliva stimulation of eight different chewing gums. International Dental Journal, 54, 143-148.

Brooks, S., \& Suchey, J. (1990). Skeletal age determination based on the os pubis, a comparison of the Ascàdi-Nemeskèri and Suchey-Brooks methods. Human Evolution, 5, 227-238.

Brothwell, D. R. (1981). Digging up bones. Ithaca, New York: Cornell University Press.

Buikstra, J. E., \& Ubelaker, D. (1994). Standards for data collection from human skeletal remains. Arkansas: Fayetteville.

Burakoff, R. P. (2003). Preventive dentistry: current concepts in women's oral health. Primary Care Update for OB/GYNS, 10(3), 141-146.

Bynum, C. W. (1985). Fast, feast, and flesh: The religious significance of food to medieval women. Representations, 11,1-25. 
Bynum, C. W. (1987). Holy feast and holy fast: The religious significance of food to medieval women (Revised ed.). Berkeley: University of California Press.

Campus, G., Lumbau, A., Lai, S., Solinas, G., \& Castiglia, P. (2001). Socioeconomic and behavioural factors related to caries in twelve-year-old sardinian children. Caries Research, 35(6), 427-434.

Candilio, F., \& Cox, S. (2016). Demography. In E. Fentress, C. Goodson, \& M. Maiuro (Eds.), Villa Magna: An Imperial Estate and its Legacies, Excavations 2006-10, Archaeological Monographs of the British School at Rome, 22 (pp. 379-393). London: British School at Rome.

Choi, B. K., Paster, B. J., Dewhirst, F. E., \& Göbel, U. B. (1994). Diversity of cultivable and uncultivable oral spirochetes from a patient with severe destructive periodontitis. Infection and Immunnity, 62(5), 1889-1895.

Clarke, N., \& Hirsche, R. (1991). Physiological, pulpal, and periodontal factors influencing alveolar bone. In M. Kelly \& C. S. Larsen (Eds.), Advances in dental anthropology (pp. 241-266). New York: Wiley-Liss.

Cleaton-Jones, P., Richardson, B. D., Granath, L., Fatti, L. P., Sinwell, R., Walker, A. R., \& Mogotsi, M. (2000). Nutritional status and dental caries in a large sample of 4- and 5-year-old South African children. South African Medical Journal, 90(6), 631-635.

Cohen, M. N., \& Armelagos, G. J. (1984). Paleopathology at the origins of agriculture. Orlando, FL: Academic Press.

Cohen, M. N., \& Cane-Kramer, G. M. M. (2007). Ancient health: Skeletal indicators of agricultural, and economic intensification. Gainesville: University Press of Florida.

Corraini, P., Baelum, V., Pannuti, C. M., Pustiglioni, A. N., Romito, G. A., \& Pustiglioni, F. E. (2009). Tooth loss prevalence and risk indicators in an isolated population of Brazil. Acta Odontologica Scandinavica, 67(5), 297-303.

Costa, R. L. (1982). Periodontal disease in the prehistoric Ipiutak and Tigara skeletal remains from Point Hope, Alaska. American Journal of Physical Anthropology, 59(1), 97-110.

Craddock, H. L., \& Youngson, C. C. (2004). Eruptive tooth movement - the current state of knowledge. British Dental Journal, 197(7), 385-391.

Cucina, A., \& Tiesler, V. (2003). Dental caries and antemortem tooth loss in the Northern Peten area, Mexico: A biocultural perspective on social status differences among the Classic Maya. American Journal of Physical Anthropology, 122(1), 1-10.

DaGloria, P., \& Larsen, C. S. (2014). Oral health of the Paleoamericans of Lagoa Santa, Central Brazil. American Journal of Physical Anthropology, 154(1), 11-26.

Dawes, C., \& Kubieniec, K. (2004). The effects of prolonged gum chewing on salivary flow rate and composition. Archives of Oral Biology, 49, 665-669.

Dawes, C., \& Macpherson, L. M. (1992). Effects of nine different chewinggums and lozenges on salivary flow rate and $\mathrm{pH}$. Caries Research, 26, 176-182.

Deeley, K., Letra, A., Rose, E. K., Brandon, C. A., Resick, J. M., Marazita, M. L., \& Vieira, A. R. (2008). Possible association of amelogenin to high caries experience in a Guatemalan-Mayan population. Caries Research, 42(1), 8-13.

DePaola, P., Soparker, P., Tavares, M., Allukian, M., \& Peterson, H. (1982). A dental survey of Massachusetts school children. Journal of Dental Research, 61, 1356-1360.

Dewhirst, F. E., Chen, T., Izard, J., Paster, B. J., Tanner, A. C. R., Yu, W. H., ... Wade, W. G. (2010). The human oral microbiome. Journal of Bacteriology, 192(19), 5002-5017.

DeWitte, S. N., \& Bekvalac, J. (2010). Oral health and frailty in the medieval English cemetery of St Mary Graces. American Journal Physical Anthropology, 142(3), 341-354.

Dias, G., \& Tayles, N. (1997). 'Abscess cavity'-a misnomer. International Journal of Osteoarchaeology, 7(7), 548-554.

Dodds, M. W. J., \& Johnson, D. A. (1993). Influence of mastication on saliva, plaque $\mathrm{pH}$ and masseter muscle activity in man. Archives of Oral Biology, 38(7), 623-626.

Dodds, M. W., Hsieh, S. C., \& Johnson, D. A. (1991). The effect of increased mastication by daily gum-chewing on salivary gland output and dental plaque acidogenicity. Journal of Dental Research, 70(12), 1474-1478

Dodds, M. W. J., Johnson, D. A., \& Yeh, C. K. (2005). Health benefits of saliva: a review. Journal of Dentistry, 33(3), 223-233.
Douglas, M. (2006). Subsistence change and dental health in the people of Non Nok Tha, northeast Thailand. In M. Oxenham \& N. Tayles (Eds.), Bioarchaeology of Southeast Asia (pp. 191-219). Cambridge: Cambridge University Press.

Dowd, F. J. (1999). Saliva and dental caries. Dental Clinics of North America, 43(4), 579-597.

Eke, P. I., Dye, B. A., Wei, L., Slade, G. D., Thornton-Evans, G. O., Borgnakke, W. S., ... Genco, R. J. (2015). Update on prevalence of periodontitis in adults in the United States: NHANES 2009 to 2012. Journal of Periodontology, 86(5), 611-622.

Fentress, E., \& Maiuro, M. (2011). Villa Magna near Anagni: The emperor, his winery and the wine of Signia. Journal of Roman Archaeology, 24, 333-369.

Fentress, E., Goodson, C., \& Maiuro, M. (2016). Villa Magna: an Imperial Estate and its Legacies. Excavations 2006-10, Archaeological Monographs of the British School at Rome, 22. London: British School at Rome.

Fields, M., Herschaft, E. E., Martin, D. L., \& Watson, J. T. (2009). Sex and the agricultural transition: Dental health of early farming females. Journal of Dental Oral Hygiene, 1(4), 42-51.

Fraser, R. A., Bogaard, A., Heaton, T., Charles, M., Jones, G., Christensen, B. T., ... Styring, A. K. (2011). Manuring and stable nitrogen isotope ratios in cereals and pulses: Towards a new archaeobotanical approach to the inference of land use and dietary practices. Journal of Archaeological Science, 38(1), 2790-2804.

Freeman, R., Maizels, J., Wyllie, M., \& Sheiham, A. (1993). The relationship between health related knowledge, attitudes and dental health behaviours in 14-16-year-old adolescents. Community Dental Health, 10(4), 397-404.

García-Godoy, F., \& Hicks, M. J. (2008). Maintaining the integrity of the enamel surface: The role of dental biofilm, saliva and preventive agents in enamel demineralization and remineralization. Journal of the American Dental Association, 139(S2), 25S-34S.

Gavião, M. B. D., Engelen, L., \& van der Bilt, A. (2004). Chewing behavior and salivary secretion. European Journal of Oral Science, 112, 19-24.

Goodson, C. (2016). Villamagna in the middle ages. In E. Fentress, C. Goodson, \& M. Maiuro (Eds.), Villa Magna: An imperial estate and its Legacies, Excavations 2006-10, Archaeological Monographs of the British School at Rome, 22 (pp. 410-419). London: British School at Rome.

Griffen, A. L., Beall, C. J., Campbell, J. H., Firestone, N. D., Kumar, P. S., Yang, Z. K., ... Leys, E. J. (2012). Distinct and complex bacterial profiles in human periodontitis and health revealed by $16 \mathrm{~S}$ pyrosequencing. Multidisciplinary Journal of Microbial Ecology, 6(6), 1176-1185.

Hajishengallis, G., \& Lamont, R. J. (2012). Beyond the red complex and into more complexity: the polymicrobial synergy and dysbiosis (PSD) model of periodontal disease etiology. Molecular Oral Microbiology, 27(6), 409-419.

Hall, H. D., \& Schneyer, C. A. (1964). Salivary gland atrophy in rat induced by liquid diet. Proceedings of the Society for the Experimental Biology and Medicine, Society for Experimental Bology and Medicine, 117, 789-793.

Hand, A. R., Pathmanathan, D., \& Field, R. B. (1999). Morphological features of the minor salivary glands. Archives of Oral Biology, 44, S3-S10.

Hara, A. T., Ando, M., González-Cabezas, C., Cury, J. A., Serra, M. C., \& Zero, D. T. (2006). Protective effect of the dental pellicle against erosive challenges in situ. Journal of Dental Research, 85(7), 612-616.

Hatch, J. P., Shinkai, R. S. A., Sakai, S., Rugh, J. D., \& Paunovich, E. D. (2000). Determinants of masticatory performance in dentate adults. Archives of Oral Biology, 46, 641-648.

Hector, M. P., \& Linden, R. W. A. (1987). The possible role of periodontal mechanoreceptors in the control of parotid secretion in man. Quarterly Journal of Experimental Physiology, 72(3), 285-301.

Hernández, M., Dutzan, N., García-Sesnich, J., Abusleme, L., Dezerega, A., Silva, N., ... Gamonal, J. (2011). Host-pathogen interactions in progressive chronic periodontitis. Journal of Dental Research, 90(10), 1164-1170.

Hildebolt, C., \& Molnar, S. (1991). Measurement and description of periodontal disease in anthropological studies. In M. Kelley \& C. S. Larsen (Eds.), Advances in dental anthropology (pp. 225-240). New York: Wiley-Liss.

Hillson, S. (2000). Dental pathology. In M.A. Katzenberg MA, S.R. Saunders (Eds.), Biological anthropology of the human skeleton. New York: WileyLiss. pp. 249-286. 
Hillson, S. (2001). Recording dental caries in archaeological human remains. International Journal of Osteoarchaeology, 11, 249-289.

Hillson, S. (2008). Dental anthropology. Cambridge UK: Cambridge University Press.

Holt, E. (2016). In E. Fentress, C. Goodson, \& M. Maiuro (Eds.), Villa Magna: An imperial estate and its legacies, Excavations 2006-10, Archaeological Monographs of the British School at Rome, 22 (pp. 328-335). London: British School at Rome.

Ikebe, K., Matsuda, K., Morii, K., Hazeyama, T., Kagawa, R., Ogawa, T., \& Nokubi, T. (2007). Relationship between bite force and salivary flow in older adults. Oral Surgery, Oral Medicine, Oral Patholology, Oral Radiolology, and Endodontology, 104(4), 510-515.

Infante, P. F., \& Gillespie, G. M. (1976). Dental caries experience in the deciduous dentition of rural Guatemalan children ages 6 months to 7 years. Journal of Dental Research, 55(6), 951-957.

Infante, P. F., \& Gillespie, G. M. (1977). Enamel hypoplasia in relation to caries in Guatemalan children. Journal of Dental Research, 56(5), 493-498.

İscan, M., Loth, S., \& Wright, R. (1984). Age estimation from the rib by phase analysis: White males. Journal of Forensic Sciences, 29, 10941104.

İşcan, M., Loth, S., \& Wright, R. (1985). Age estimation from the rib by phase analysis: White females. Journal of Forensic Sciences, 30, 853-863.

Jackes, M. (2000). Building the bases for paleodemographic analyses: Adult age determination. In M. A. Katzenberg \& S. R. Saunders (Eds.), Biological Anthropology of the Human Skeleton (pp. 417-466).

Jenkins, G. N., \& Edgar, W. M. (1989). The effect of daily gum-chewing on salivary flow rates in man. Journal of Dental Research, 68(5), 786-790.

Jepsen, S., Deschner, J., Braun, A., Schwarz, F., \& Eberhard, J. (2011). Calculus removal and the prevention of its formation. Periodontology, 2000(55), 167-188.

Johansson, I., Ericson, T., \& Steen, L. (1984). Studies of the effect of diet on saliva secretion and caries development: the effect of fasting on saliva composition of female subjects. The Journal of Nutrition, 114(11), 2010-2020.

Johnson, D. A. (1984). Changes in rat parotid salivary proteins associated with liquid diet-induced gland atrophy and isoproterenol-induced gland enlargement. Archives of Oral Biology, 29(3), 215-221.

Johnson, D. A., \& Sreebny, L. M. (1973). Effect of increased mastication on the secretory process of the rat parotid gland. Archives Oral Biology, 18 (12), 1555-1557.

Jones, R. (2004). Signatures in the soil: The use of pottery in manure scatters in the identification of medieval Arable farming regimes. Archaeological Journal, 16(1), 159-188.

Julien, K. C., Buschang, P. H., Throckmorton, G. S., \& Dechow, P. C. (1996). Normal masticatory performance in young adults and children. Archives of Oral Biology, 41, 69-75.

Kaidonis, J. A. (2008). Tooth wear: The view of the anthropologist. Clinical Oral Investigations, 12(S1), 21-26.

Kaidonis, J. A., Richards, L. C., \& Townsend, G. C. (1993). Nature and frequency of dental wear facets in an Australian aboriginal population. Journal of Oral Rehabilitation, 20(3), 333-340.

Kanchanakamol, U., Tuongratanaphan, S., Tuongratanaphan, S., Lertpoonvilaikul, W., Chittaisong, C., Pattanaporn, K., ... Davies, G. N. (1996). Prevalence of developmental enamel defects and dental caries in rural pre-school Thai children. Community Dental Health, 13(4), 204-207.

Kelley, M., Levesque, D., \& Weidle, E. (1991). Contrasting patterns of dental disease in five early northern Chilean groups. In M. Kelley \& C. S. Larsen (Eds.), Advances in dental anthropology (pp. 179-202). New York: Wiley-Liss.

Kerr, N. W. (1988). A method of assessing periodontal status in archaeologically derived skeletal material. Journal of Paleopathology, 2(2), 67-78.

Kerr, N. W. (1991). Prevalence and natural history of periodontal disease in Scotland - the medieval period (900-1600 A.D.). Journal of Periodontal Research, 26(4), 346-354.

Klaus, H. D., \& Tam, M. E. (2010). Oral health and the postcontact adaptive transition: A contextual reconstruction of diet in Mórrope, Peru: Oral health in Postcontact Peru. American Journal of Physical Anthropology, 141(4), 594-609.
Kolenbrander, P. E., \& Palmer, R. J. (2004). Human oral bacterial biofilms. In M. Ghannoum \& M. A. O'Toole (Eds.), Microbial biofilms (pp. 85-117). Washington, D.C.: ASM Press.

Laine, M. A. (2002). Effect of pregnancy on periodontal and dental health. Acta Odontologica Scandinavica, 60(5), 257-264.

Larsen, C. S. (1983). Behavioural implications of temporal change in cariogenesis. Journal of Archaeology Science, 10(1), 1-8.

Larsen, C.S. (1997, 2015). Bioarchaeology: Interpreting behavior from the human skeleton. Cambridge: Cambridge University Press.

Larsen, C.S. (1998). Gender, health and activity in foragers and farmers in the American Southeast: Implications for Social Organization in the Georgia Bight. In A. Grauer A, P. Stuart-Macadam (Eds.), Sex and gender in paleopathological perspective. Cambridge: University of Cambridge Press, pp 165-87.

Larsen, C. S., \& Milner, G. R. (1994). In the wake of contact: Biological responses to conquest. New York: Wiley-Liss.

Larsen, C. S., Shavit, R., \& Griffin, M. C. (1991). Dental caries evidence for dietary change: An archaeological context. In M. Kelley \& C. S. Larsen (Eds.), Advances in dental anthropology (pp. 179-202). New York: WileyLiss.

Lenander-Lumikari, M., \& Loimaranta, V. (2000). Saliva and dental caries. Advancements in Dental Research, 14, 40-47.

Leroy, R., Bogaerts, K., Lesaffre, E., \& Declerck, D. (2005). Multivariate survival analysis for the identification of factors associated with cavity formation in permanent first molars. European Journal of Oral Sciences, 113(2), 145-152.

Li, Y., Navia, J. M., \& Bian, J. Y. (1996). Caries experience in deciduous dentition of rural Chinese children 3-5 years old in relation to the presence or absence of enamel hypoplasia. Caries Research, 30(1), 8-15.

Loesche, W. J. (1986). Role of Streptococcus mutans in human dental decay. Microbiological Reviews, 50(4), 353-380.

López, R., \& Baelum, V. (2006). Gender differences in tooth loss among Chilean adolescents: Socio-economic and behavioral correlates. Acta Odontologica Scandinavica, 64(3), 169-176.

Lovejoy, C. O. (1985). Dental wear in the Libben population: Its functional pattern and role in the determination of adult skeletal age at death. American Journal of Physical Anthropology, 68(1), 47-56.

Lovejoy, C. O., Meindl, R. S., Pryzbeck, T. R., \& Mensforth, R. P. (1985). Chronological metamorphosis of the auricular surface of the ilium: $A$ new method for the determination of adult skeletal age at death. American Journal of Physical Anthropology, 68(10), 15-28.

Lucas, P. (2004). Dental functional morphology: How teeth work. Cambridge, UK: Cambridge University Press.

Lukacs, J. R. (1992). Dental paleopathology and agricultural intensification in south Asia: New evidence from Bronze Age Harappa. American Journal of Physical Anthropology, 87(2), 133-150.

Lukacs, J. R. (1995). The 'caries correction factor': A new method of calibrating dental caries rates to compensate for antemortem loss of teeth. International Journal of Osteoarchaeology, 5(2), 151-156.

Lukacs, J. R. (1996). Sex differences in dental caries rates with the origin of agriculture in South Asia. Current Anthropology, 37(1), 147-153.

Lukacs, J. R. (2007). Dental trauma and antemortem tooth loss in prehistoric Canary Islanders: Prevalence and contributing factors. International Journal of Osteoarchaeology, 17(2), 157-173.

Lukacs, J. R. (2008). Fertility and agriculture accentuate sex differences in dental caries rates. Current Anthropology, 49(5), 901-914.

Lukacs, J. R. (2012). Oral health in past populations: Context, concepts and controversies. In A. L. Grauer (Ed.), A companion to paleopathology (pp. 553-581). New Jersey: Wiley-Blackwell.

Lukacs, J. R. (2017). Bioarchaeology of oral health: Sex and gender differences in dental disease. In S. C. Agarwal \& J. K. Wesp (Eds.), Exploring sex and gender in bioarchaeology (pp. 263-290). Albuquerque: University of New Mexico Press.

Lukacs, J. R., \& Largaespada, L. L. (2006). Explaining sex differences in dental caries prevalence: Saliva, hormones, and "life-history" etiologies. American Journal of Human Biology, 18(4), 540-555.

Lukacs, J. R., \& Pal, J. (1993). Mesolithic subsistence in northern India: Inferences from dental pathology and odontometry. Current Anthropology, 34(5), 745-765. 
Mackie, D. A., \& Pangborn, R. M. (1990). Mastication and its influence on human salivary flow and alpha-amylase secretion. Physiology \& Behavior, 47, 593-595.

Marsh, P. D. (2004). Dental plaque as a microbial biofilm. Caries Research, 38(3), 204-211.

Mathew, W. M. (1993). Marling in British agriculture: A case of partial identity. Agricultural History Review, 41, 97-110.

Mays, S. (1998). Osteoporosis in earlier human populations. Journal of Clinical Densitometry, 2, 71-78.

Meisel, P., Reifenberger, J., Haase, R., Nauck, M., Bandt, C., \& Kocher, T. (2008). Women are periodontally healthier than men, but why don't they have more teeth than men? Menopause, 15(2), 270-275.

Mioche, L., Bouriol, P., Martin, J. F., \& Noël, Y. (1999). Variations in human masseter and temporalis muscle activity related to food texture during free and side-imposed mastication. Archives of Oral Biology, 44, 1005-1012.

Moore, W. E., \& Moore, L. V. (1994). The bacteria of periodontal diseases. Periodontology, 5, 66-77.

Moorrees, C. (1957). The Aleut dentition: A correlative study of dental characteristics in an Eskimoid people. Cambridge: Harvard University Press.

de Muñiz, B. R., Maresca, B. M., Tumilasci, O. R., \& Perec, C. J. (1983). Effects of an experimental diet on parotid saliva and dental plaque $\mathrm{pH}$ in institutionalized children. Archives of Oral Biology, 28(7), 575-581.

ten Cate, J. M. (2006). Biofilms, a new approach to the microbiology of dental plaque. Odontology, 94(1), 1-9.

Navazesh, M., \& Kumar, S. K. S. (2008). Measuring salivary flow: Challenges and opportunities. Journal of the American Dental Association, $139,35 \mathrm{~S}-40 \mathrm{~S}$.

Navazesh, M., Mulligan, R. A., Kipnis, V., Denny, P. A., \& Denny, P. C. (1992). Comparison of whole saliva flow rates and mucin concentrations in healthy Caucasian young and aged adults. Journal of Dental Research, 71(6), 1275-1278.

Nelson, G. C., Lukacs, J. R., \& Yule, P. (1999). Dates, caries, and early tooth loss during the Iron Age of Oman. American Journal of Physical Anthropology, 108(3), 333-343.

Newman, B. (1995). From Virile Woman to WomanChrist: Studies in Medieval Religion and Literature. Philadelphia: University of Pennsylvania Press.

Nitsch, E. (2016). Stable carbon and nitrogen isotopic analysis. In E. Fentress, C. Goodson, \& M. Maiuro (Eds.), Villa Magna: An Imperial Estate and its Legacies, Excavations 2006-10, Archaeological Monographs of the British School at Rome, 22 (pp. 393-401). London: British School at Rome.

Novak, M. (2015). Dental health and diet in early medieval Ireland. Archives of Oral Biology, 60(9), 1299-1309.

Otani, N., Hamasaki, T., Soh, I., Yoshida, A., Awano, S., Ansai, T., ... Takehara, T. (2009). Relationship between root caries and alveolar bone loss in the first wet-rice agriculturalists of the Yayoi period in Japan. Archives of Oral Biology, 54(2), 192-200.

Oyamada, J., Igawa, K., Kitagawa, Y., Manabe, Y., Kato, K., Matsushita, T., \& Rokutanda, A. (2007). Low AMTL ratios in medieval Japanese dentition excavated from Yuigahama-Minami site in Kamakura. Anthropological Science, 115, 47-53.

Pascoe, L., \& Seow, W. K. (1994). Enamel hypoplasia and dental caries in Australian aboriginal children: Prevalence and correlation between the two diseases. Pediatric Dentistry, 16(3), 193-199.

Paster, B. J., Boches, S. K., Galvin, J. L., Ericson, R. E., Lau, C. N., Levanos, V. A., ... Dewhirst, F. E. (2001). Bacterial diversity in human subgingival plaque. Journal of Bacteriology, 183(12), 3770-3783.

Paster, B. J., Olsen, I., Aas, J. A., \& Dewhirst, F. E. (2006). The breadth of bacterial diversity in the human periodontal pocket and other oral sites. Periodontology, 42, 80-87.

Patir, A., Seymen, F., Yildirim, M., Deeley, K., Cooper, M. E., Marazita, M. L., \& Vieira, A. R. (2008). Enamel formation genes are associated with high caries experience in Turkish children. Caries Research, 42(5), 394-400.

Pedersen, W., Schubert, M., Izutsu, K., Mersai, T., \& Truelove, E. (1985). Age-dependent decreases in human submandibular gland flow rates as measured under resting and post-stimulation conditions. Journal of Dental Research, 64(5), 822-825.
Percival, R. S., Challacombe, S. J., \& Marsh, P. D. (1994). Flow rates of resting whole and stimulated parotid saliva in relation to age and gender. Journal of Dental Research, 73(8), 1416-1420.

Pereira, L. J., Gavião, M. B. D., \& van der Bilt, A. (2006). Influence of ora characteristics and food products on masticatory function. Acta Odontologica Scandinavica, 64(4), 193-201.

Perinetti, G., Caputi, S., \& Varvara, G. (2005). Risk/prevention indicators for the prevalence of dental caries in schoolchildren: results from the Italian OHSAR survey. Caries Research, 39(1), 9-19.

Polland, K. E., Higgins, F., \& Orchardson, R. (2003). Salivary flow rate and $\mathrm{pH}$ during prolonged gum chewing in humans. Journal of Oral Rehabilitation, 30, 861-865.

Powell, M. L. (1985). The analysis of dental wear, and caries for dietary reconstruction. In R. I. Gilbert, Jr. \& J. H. Mielke (Eds.), The analysis of prehistoric diets (pp. 307-338). Orlando, FL: Academic Press.

Psoter, W. J., Reid, B. C., \& Katz, R. V. (2005). Malnutrition and dental caries: A review of the literature. Caries Research, 39(6), 441-447.

Psoter, W. J., Gebrian, B., Prophete, S., Reid, B., \& Katz, R. (2008a). Effect of early childhood malnutrition on tooth eruption in Haitian adolescents. Community Dentistry and Oral Epidemiology, 36(2), 179-189.

Psoter, W. J., Spielman, A. L., Gebrian, B., Rudolph, S. J., \& Katz, R. V. (2008b). Effect of childhood malnutrition on salivary flow and $\mathrm{pH}$. Archives of Oral Biology, 53(3), 231-237.

Ranganathan, P., Aggarwal, R., \& Pramesh, C. S. (2015). Common pitfalls in statistical analysis: Odds versus risk. Perspectives in Clinical Research, 6 (4), 222-224.

Reyes-Perez, E., Borrell, L. N., Katz, R. V., Gebrian, B. J., Prophete, S., \& Psoter, W. J. (2014). Effect of early childhood protein-energy malnutrition on permanent dentition dental caries. Journal of Public Health Dentistry, 74(3), 181-187.

Robb, J. (1997). Intentional tooth removal in Neolithic Italian women. Antiquity, 71, 659-669.

Rose, J. C., Marks, M. K., \& Tiezen, L. L. (1991). Bioarchaeology and subsistence in the central and lower portions of the Mississippi valley. In M. L. Powell, P. S. Bridges, \& A. M. W. Mires (Eds.), What mean these bones? Studies in southeastern bioarchaeology (pp. 7-21). Tuscaloosa: University of Alabama Press.

Rosenhek, M., MacPherson, L. M. D., \& Dawes, C. (1993). The effects of chewing-gum stick size and duration of chewing on salivary flow rate and sucrose and bicarbonate concentrations. Archives of Oral Biology, 38, 885-891.

Russell, S. L., Psoter, W. J., Jean-Charles, G., Prophte, S., \& Gebrian, B. (2010). Protein-energy malnutrition during early childhood and periodontal disease in the permanent dentition of Haitian adolescents aged 12-19 years: a retrospective cohort study. International Journal of Paediatric Dentistry, 20(3), 222-229.

Sales-Peres, S. H., \& Bastos, J. R. (2002). An epidemiological profile of dental caries in 12-year-old children residing in cities with and without fluoridated water supply in the central western area of the State of São Paulo, Brazil. Cadernos de Saude Publica, 18(5), 1281-1288.

Scott, E. C. (1979). Dental wear scoring technique. American Journal of Physical Anthropology, 51(2), 213-217.

Scott, B. J. J., Bajaj, J., \& Linden, R. W. A. (1999). The contribution of mechanoreceptive neurons in the gingival tissues to the masticatory-parotid salivary reflex in man. Journal of Oral Rehabilitation, 26, 791-797.

Sgan-Cohen, H. D., Katz, J., Horev, T., Dinte, A., \& Eldad, A. (2000). Trends in caries and associated variables among young Israeli adults over 5 decades. Community Dentistry and Oral Epidemiology, 28(3), 234-240.

Shigli, K., Hebbal, M., \& Angadi, G. S. (2009). Relative contribution of caries and periodontal disease in adult tooth loss among patients reporting to the Institute of Dental Sciences, Belgaum, India. Gerodontology, 26(3), 214-218.

Silk, H., Douglass, A. B., Douglass, J. M., \& Silk, L. (2008). Oral health during pregnancy. American Family Physician, 77(8), 1139-1144.

Šlaus, M., Bedić, A., Bradić, J., Vodanović, M., \& Brkić, H. (2017). Endemic warfare and dental health in historic period archaeological series from Croatia. International Journal of Osteoarchaeology, 28(1), 65-74.

Slomiany, B. L., Murty, V. L., Piotrowski, J., \& Slomiany, A. (1996). Salivary mucins in oral mucosal defense. General Pharmacology, 27(5), 761-771. 
Smith, B. H. (1984). Patterns of molar wear in hunter-gatherers and agriculturalists. American Journal of Physical Anthropology, 63(1), 39-56.

Socransky, S. S., Haffajee, A. D., Cugini, M. A., Smith, C., \& Kent, R. L. (1998). Microbial complexes in subgingival plaque. Journal of Clinical Periodontology, 25(2), 134-144.

Sreebny, L. M. (2000). Saliva in health and disease: an appraisal and update. International Dental Journal, 50(3), 140-161.

Steinberg, B. J. (2000). Women's oral health issues. Journal of the California Dental Association, 28(9), 663-667.

Streckfus, C. F., Baur, U., Brown, L. J., Bacal, C., Metter, J., \& Nick, T. (1998). Effects of estrogen status and aging on salivary flow rates in healthy Caucasian women. Gerontology, 44(1), 32-39.

Suni, J., Helenius, H., \& Alanen, P. (1998). Tooth and tooth surface survival rates in birth cohorts from 1965, 1970, 1975, and 1980 in Lahti, Finland. Community Dentistry and Oral Epidemiology, 26(2), 101-106.

Sweeney, E. A., \& Guzman, M. (1966). Oral conditions in children from three highland villages in Guatemala. Archives of Oral Biology, 11(7), 687-698.

Sweeney, E. A., Saffir, A. J., \& De Leon, R. (1971). Linear hypoplasia of deciduous incisor teeth in malnourished children. American Journal of Clinical Nutrition, 24(1), 29-31.

Tabak, L. A., Levine, M. J., Mandel, I. D., \& Ellison, S. A. (1982). Role of salivary mucins in the protection of the oral cavity. Journal of Oral Pathology and Medicine, 11(1), 1-17.

Tayles, N., Domett, K., \& Nelsen, K. (2000). Agriculture and dental caries? The case of rice in prehistoric Southeast Asia. World Archaeology, 32, 68-83.

Temple, D. H. (2007). Dietary variation and stress among prehistoric Jomon foragers from Japan. American Journal of Physical Anthropology, 133(4), 1035-1046.

Temple, D. H. (2011). Variability in dental caries prevalence between male and female foragers from the Late/Final Jomon period: Implications for dietary behavior and reproductive ecology. American Journal of Hum Biology, 23(1), 107-117.

Temple, D. H., \& Larsen, C. S. (2007). Dental caries prevalence as evidence for agriculture and subsistence variation during the Yayoi period in prehistoric Japan: Biocultural interpretations of an economy in transition. American Journal of Physical Anthropology, 134(4), 501-512.

Turner, C. G. (1979). Dental anthropological indications of agriculture among the Jomon people of central Japan. American Journal of Physical Anthropology, 51(4), 619-635.

Van der Bilt, A., Oltohoff, L. W., Bosman, F., \& Oosterhaven, S. P. (1994). Chewing performance before and after rehabilitation of post-canine teeth in man. Journal of Dental Research, 73(11), 1677-1683.
Varrela, T. M., Paunio, K., Wouters, F. R., Tiekso, J., \& Söder, P. O. (1995). The relation between tooth eruption and alveolar crest height in a human skeletal sample. Archives of Oral Biology, 40(3), 175-180.

Vissink, A., Spijkervet, F. K., \& Van Nieuw Amerongen, A. (1996). Aging and saliva: A review of the literature. Special Care in Dentistry, 16(3), 95-103.

Vitorino, R., Calheiros-Lobo, M. J., Duarte, J. A., Domingues, P., \& Amado, F. (2006). Salivary clinical data and dental caries susceptibility: Is there a relationship? Bulletin Du Groupement International Pour La Recherche Scientifique En Stomatolgie \& Odontolgie, 47(1), 27-33.

Walker, P., \& Hewlett, B. (1990). Dental health, diet, and social status among Central African foragers and farmers. American Anthropologist, 92, 383-398.

Wasterlain, S. N., Cunha, E., \& Hillson, S. (2011). Periodontal disease in a Portuguese identified skeletal sample from the late nineteenth and early twentieth centuries. American Journal of Physical Anthropology, 145(1), 30-42.

Watson, J., Fields, M., \& Martin, D. (2010). Introduction of agriculture and its effects on women's oral health. American Journal of Human Biology, 22, 92-102.

White, D. J. (1997). Dental calculus: Recent insights into occurrence, formation, prevention, removal and oral health effects of supragingival and subgingival deposits. European Journal of Oral Sciences, 105(5), 508-522.

Whittaker, D. K., \& Molleson, T. (1996). Caries prevalence in the dentition of a late eighteenth century population. Archives of Oral Biology, 41(1), 55-61.

Yeh, C. K., Johnson, D. A., Dodds, M. W., Sakai, S., Rugh, J. D., \& Hatch, J. P. (2000). Association of salivary flow rates with maximal bite force. Journal of Dental Research, 79(8), 1560-1565.

Younes, S. A. E. S., \& El-Angbawi, M. F. (1982). Dental caries prevalence in intermediate Saudi schoolchildren in Riyad. Community Dentistry and Oral Epidemiology, 10(2), 74-76.

\section{SUPPORTING INFORMATION}

Additional supporting information may be found online in the Supporting Information section at the end of this article.

How to cite this article: Trombley TM, Agarwal SC, Beauchesne PD, et al. Making sense of medieval mouths: Investigating sex differences of dental pathological lesions in a late medieval Italian community. Am J Phys Anthropol. 2019; 169:253-269. https://doi.org/10.1002/ajpa.23821 